\title{
Transport and Residence Times of Tropospheric Aerosols Inferred from a Global Three-Dimensional Simulation of ${ }^{210} \mathrm{~Pb}$.
}

\author{
YVES J. BALKANSKI, ${ }^{1}$ DANIEL J. JACOB, AND GERALDINE M. GARDNER \\ Department of Earth and Planetary Sciences and Division of Applied Sciences \\ Harvard University, Cambridge, Massachusetts \\ William C. Graustein and Karl K. Turekian \\ Department of Geology and Geophysics, Yale University, New Haven, Connecticut
} \begin{abstract}
A global three-dimensional model is used to investigate the transport and tropospheric residence time of
${ }^{210} \mathrm{~Pb}$, an aerosol tracer produced in the atmosphere by radioactive decay of ${ }^{222} \mathrm{Rn}$ emitted from soils. The model uses meteorological input with $4^{\circ} \times 5^{\circ}$ horizontal resolution and 4-hour temporal resolution from the Goddard Institute for Space Studies general circulation model (GCM). It computes aerosol scavenging by convective precipitation as part of the wet convective mass transport operator in order to capture the coupling between vertical transport and rainout. Scavenging in convective precipitation accounts for $74 \%$ of the global ${ }^{210} \mathrm{~Pb}$ sink in the model; scavenging in large-scale precipitation accounts for $12 \%$, and scavenging in dry deposition accounts for $14 \%$. The model captures $63 \%$ of the variance of yearly mean ${ }^{210} \mathrm{~Pb}$ concentrations measured at 85 sites around the world with negligible mean bias, lending support to the computation of aerosol scavenging. There are, however, a number of regional and seasonal discrepancies that reflect in part anomalies in GCM precipitation. Computed residence times with respect to deposition for ${ }^{210} \mathrm{~Pb}$ aerosol in the tropospheric column are about 5 days at southern midlatitudes and 10-15 days in the tropics; values at northern midlatitudes vary from about 5 days in winter to 10 days in summer. The residence time of ${ }^{210} \mathrm{~Pb}$ produced in the lowest $0.5 \mathrm{~km}$ of atmosphere is on average four times shorter than that of ${ }^{210} \mathrm{~Pb}$ produced in the upper atmosphere. Both model and observations indicate a weaker decrease of ${ }^{210} \mathrm{~Pb}$ concentrations between the continental mixed layer and the free troposphere than is observed for total aerosol concentrations; an explanation is that ${ }^{222} \mathrm{Rn}$ is transported to high altitudes in wet convective updrafts, while aerosols and soluble precursors of aerosols are scavenged by precipitation in the updrafts. Thus ${ }^{210} \mathrm{~Pb}$ is not simply a tracer of aerosols produced in the continental boundary layer, but also of aerosols derived from insoluble precursors emitted from the surface of continents. One may draw an analogy between ${ }^{210} \mathrm{~Pb}$ and nitrate, whose precursor $\mathrm{NO}_{\mathrm{x}}$ is sparingly soluble, and explain in this manner the strong correlation observed between nitrate and ${ }^{210} \mathrm{~Pb}$ concentrations over the oceans.
\end{abstract}

\section{INTRODUCTION}

Tropospheric aerosols increase the albedo of the Earth directly by scattering and also indirectly by modifying the microstructures of clouds. Several papers have argued that the increase in albedo due to anthropogenic aerosols over the past century could have largely offset the concurrent increase in greenhouse radiative forcing [Charlson et al., 1991, 1992; Penner et al., 1991]. This albedo effect depends critically on the extent of anthropogenic aerosol influence in the remote troposphere [Schwartz, 1988; Twomey, 1991; Kiehl and Briegleb, 1993], which may be limited by efficient scavenging of aerosols in precipitation. Literature estimates for the residence times of aerosols in the troposphere range from 4 to 60 days [Martell and Moore, 1974; Giorgi and Chameides, 1986; Graustein and Turekian, 1986]. At the low end of this range the aerosols are confined to their region of origin, while at the high end they may be transported on a hemispheric scale. The wide range of aerosol residence times reflects in part uncertainty in the estimates and in part a real dependence of the residence time on the origin of the aerosol, its size distribution,

${ }^{1}$ Now at Laboratoire de Modelisation du Climat et de l'Environnement, CEA-DSM, CE Saclay, Orme des Merisiers, Gif-sur-Yvette Cedex, France.

Copyright 1993 by the American Geophysical Union.

Paper number 93JD02456.

0148-0227/93/93JD-02456\$05.00 and the regional frequency of precipitation [Giorgi and Chameides, 1986; Joussaume, 1990]. Improved understanding of aerosol transport and residence times is needed for assessing aerosol influences on climate.

We examine in this paper the atmospheric transport of ${ }^{210} \mathrm{~Pb}$, an aerosol tracer produced in the atmosphere by radioactive decay of ${ }^{222} \mathrm{Rn}$ emitted from soils. Because of its low vapor pressure, ${ }^{210} \mathrm{~Pb}$ attaches indiscriminately to aerosol surfaces; its size distribution is concentrated in the 0.1 to $1 \mu \mathrm{m}$ range [Moore et al., 1980; Sanak et al., 1981; Bondietti et al., 1987, 1988]. Our analysis is based on a three-dimensional chemical tracer model using meteorological input from a general circulation model (GCM) developed at the Goddard Institute for Space Studies (GISS) [Hansen et al., 1983]. This chemical tracer model has been applied previously to simulate the distributions of chlorofluorocarbons [Prather et al., 1987], ${ }^{85} \mathrm{Kr}$ [Jacob et al., 1987], methylchloroform [Spivakovsky et al., 1990], ${ }^{222} \mathrm{Rn}$ [Jacob and Prather 1990; Balkanski and Jacob, 1990; Balkanski et al., 1992], and $\mathrm{O}_{3}$ and its precursors over North America [Jacob et al., 1993]. The ${ }^{210} \mathrm{~Pb}$ study was designed to test the ability of the model to simulate the transport and scavenging of soluble species. Long-term time series of ${ }^{210} \mathrm{~Pb}$ concentration measurements are available from many sites around the world, offering good constraints for model evaluation. Our previous simulations of ${ }^{222} \mathrm{Rn}$ indicated good agreement with observed concentrations, lending confidence in the computation of the ${ }^{210} \mathrm{~Pb}$ source.

The aerosol scavenging scheme used here improves on previous global three-dimensional models by computing scavenging in 
convective precipitation as part of the convective mass transport operator rather than separately as a first-order rainout loss. The latter approach has two major problems that could lead to overprediction of aerosol concentrations. First, it fails to capture the rapid processing of air through a convective updraft during a model time step, which increases the total mass of aerosol exposed to precipitation compared to that in a static atmosphere [Xing and Chameides, 1990]. Second, by splitting the convective mass transport and rainout calculations, it allows soluble tracers to be pumped in a convective updraft and disperse at the top without experiencing scavenging.

The need for coupling aerosol scavenging and wet convective mass transport in models has been pointed out previously by Rodhe [1983] and Feichter et al. [1991]. Feichter et al. [1991] presented a global three-dimensional simulation of ${ }^{210} \mathrm{~Pb}$ using a first-order rainout scheme to compute aerosol deposition. Their simulated ${ }^{210} \mathrm{~Pb}$ concentrations in surface air were on average $40 \%$ too high, while their ${ }^{210} \mathrm{~Pb}$ deposition fluxes were $18 \%$ too low. They attributed the overprediction of concentrations to insufficient aerosol scavenging in convective updrafts. The underprediction of deposition fluxes is indicative of insufficient ${ }^{222} \mathrm{Rn}$ emission; they assumed a uniform ${ }^{222} \mathrm{Rn}$ emission flux of 0.72 atom $\mathrm{cm}^{-2} \mathrm{~s}^{-1}$ from land, based on an estimate of the global mean by Lambert et al. [1982], but Lambert and his colleagues have since revised that estimate to 0.95 atom $\mathrm{cm}^{-2} \mathrm{~s}^{-1}$ (G. Polian, personal communication, 1992). Increasing ${ }^{222} \mathrm{Rn}$ emission in the model of Feichter et al. [1991] would aggravate the bias in the simulation of observed ${ }^{210} \mathrm{~Pb}$ concentrations. Our model affords substantial improvement, as discussed below.

Section 2 describes the model with particular focus on the treatment of aerosol deposition. Model results are evaluated with observations in section 3 . Aerosol residence times are discussed in section 4 . Conclusions are in section 5.

\section{MODEL DESCRIPTION}

\section{General}

Radon 222 (half-life, 3.8 days) is emitted from the Earth's surface and decays to ${ }^{210} \mathrm{~Pb}$ (half-life, 22 years), which is removed by deposition. Our model solves the mass conservation equations for ${ }^{222} \mathrm{Rn}$ and ${ }^{210} \mathrm{~Pb}$ on a global three-dimensional grid with $4^{\circ} \times 5^{\circ}$ resolution in the horizontal and nine layers in the vertical extending from the surface to $10 \mathrm{mb}$ along a sigma coordinate. The grid replicates that of the GISS GCM II [Hansen et al., 1983]. The three lowest layers extend approximately 500, 1200 , and $2600 \mathrm{~m}$ above the Earth's surface; the tropospheric column is represented by six to eight layers depending on latitude and season. A 1-year archive of GCM output is used as input to the model (Table 1). The time step is 4 hours, and meteorological quantities are updated at the end of each time step.

The computation of mass transport is as described by Prather et al. [1987], with in addition a diurnal mixed layer as described by Jacob and Prather [1990]. Convective mass fluxes are computed with the procedures used in the GCM to transport heat and momentum [Hansen et al., 1983]. When an air column is unstable with respect to the dry adiabat (dry convection), the air within that column is mixed uniformly over the time step. When an air column is unstable with respect to the wet adiabat (wet convection), $50 \%$ of the air in the lowest layer is moved directly to the highest layer, with no entrainment, and this is followed immediately by subsidence in the intermediate layers as necessary to conserve mass. The wet convection scheme allows for rapid injection of surface air to high altitudes in cloud updrafts.
TABLE 1. GISS GCM Archive Used as Model Input

\begin{tabular}{lc}
\hline Variable & Temporal Resolution \\
\hline Surface pressure & 4 hours \\
Wind velocity & 4 hours \\
Mixed layer depth $^{*}$ & 4 hours \\
Convective events, column total $^{\dagger}$ & 4 hours \\
Convective events, vertical distribution $^{\dagger}$ & 5 days \\
Precipitation, surface $^{\ddagger}$ & 4 hours \\
Precipitation, vertical distribution $^{\ddagger}$ & 5 days \\
Cloud optical depth, total $^{\mp}$ & 4 hours \\
Temperature, surfacel $^{*}$ & 5 days \\
\hline
\end{tabular}

The archive contains 1 year of GCM data with $4^{\circ} \times 5^{\circ}$ resolution in the horizontal and nine layers in the vertical.

"Vertical extent of dry convective instability initiated by surface heating.

${ }^{\dagger}$ Separate statistics are kept for the frequencies of dry, shallow wet, and deep wet convection events. Shallow wet convection is defined as not extending above layer $3(\approx 2600 \mathrm{~m}$ altitude). The vertical distribution of convective events between pairs of layers in a grid column is computed at each 4-hour model time step by scaling the 5-day mean vertical distribution to the 4-hour column totals. The convective mass fluxes are computed from the frequencies of convection events as described by Prather et al. [1987].

${ }^{\ddagger}$ Separate statistics are kept for convective and large-scale precipitation. The vertical distribution of precipitation in a grid column is computed at each 4-hour model time step by scaling the 5-day mean statistics to the 4-hour precipitation at the surface.

-Used for computing resistances to dry deposition.

Emission of ${ }^{222} \mathrm{Rn}$ from land is reduced by a factor of 3 when the surface temperature drops below $273 \mathrm{~K}$.

We assume a uniform ${ }^{222} \mathrm{Rn}$ emission flux of 1.0 atom $\mathrm{cm}^{-2} \mathrm{~s}^{-1}$ from land under nonfreezing conditions [Wilkening et al., 1975; Turekian et al., 1977; G. Polian, personal communication, 1992]. This flux is reduced by a factor of 3 under freezing conditions [Jacob and Prather 1990]. A weak emission flux of 0.005 atom $\mathrm{cm}^{-2} \mathrm{~s}^{-1}$ is assumed from oceans and lakes [Wilkening and Clements, 1975]. Emission from ice sheets is negligible [Wilkening et al., 1975]. Land, water, and ice surfaces are specified with $1^{\circ} \times 1^{\circ}$ resolution [Matthews, 1983]. Our model shows no mean bias in the simulation of ${ }^{210} \mathrm{~Pb}$ deposition fluxes, as discussed below, indicating that 1.0 atom $\mathrm{cm}^{-2} \mathrm{~s}^{-1}$ is a good estimate for the global mean ${ }^{222} \mathrm{Rn}$ emission flux from land.

Spatial and temporal variability of ${ }^{222} \mathrm{Rn}$ soil emission may be an important source of uncertainty in simulating the distribution of ${ }^{210} \mathrm{~Pb}$. Emission fluxes measured at individual sites vary over 3 orders of magnitude [Turekian et al., 1977; Schery et al., 1989; Graustein and Turekian, 1990], reflecting a number of factors that are difficult to constrain in models, including the soil abundance of the parent ${ }^{226} \mathrm{Ra}$ and the location of ${ }^{226} \mathrm{Ra}$ in the soil grains. Observations further indicate a seasonal cycle of ${ }^{222} \mathrm{Rn}$ emission beyond that due to soil freezing [Dorr and Munnich, 1990; Jacob and Prather, 1990; Ussler et al., 1993]; the amplitude and phase of this cycle varies from site to site in a manner that is not understood. Soil moisture could be an important factor affecting ${ }^{222} \mathrm{Rn}$ emission, but the dependence of ${ }^{222} \mathrm{Rn}$ emission on soil moisture is complicated [Schery et al., 1989; Jacob and Prather 1990 , and references therein].

The ability of our model to reproduce observed ${ }^{222} \mathrm{Rn}$ concentrations is in fact better than would be expected from the 
above discussion. Mean monthly afternoon concentrations of ${ }^{222} \mathrm{Rn}$ observed at sites in the continental United States are reproduced to within $20 \%$ in most cases [Jacob and Prather 1990]. Amplitudes of high- ${ }^{222} \mathrm{Rn}$ episodes observed at islands in the Subantarctic Indian Ocean are simulated to within a factor of 2 [Balkanski and Jacob, 1990]. Mean ${ }^{222} \mathrm{Rn}$ concentrations measured over the north Pacific from ships are reproduced to within $20 \%$, while aircraft observations at $8-12 \mathrm{~km}$ over the same region are underpredicted by $30 \%$ [Balkanski et al., 1992]. The relatively good agreement between model and observations may be explained by regional-scale smoothing of ${ }^{222} \mathrm{Rn}$ emission. Some evidence for this smoothing is offered by a high-resolution map of ${ }^{226} \mathrm{Ra}$ soil concentrations in the western United States [Moed et al., 1984], which indicates a factor of 20 variation from site to site but less than a factor of 3 variation at the $4^{\circ} \times 5^{\circ}$ scale. A detailed study of ${ }^{222} \mathrm{Rn}$ emission from Australian soils by Schery et al. [1989] indicates 3 orders of magnitude variation in fluxes from site to site but a continental mean flux of 1.05 atoms $\mathrm{cm}^{-2} \mathrm{~s}^{-1}$ that is consistent with our model value.

\section{Aerosol Deposition}

The GISS GCM distinguishes between two types of precipitation, convective and large scale. Convective precipitation is triggered by conditionally unstable conditions in the GCM column, resulting in an immediate updraft with compensatory subsidence. Large-scale precipitation is triggered by water vapor saturation in a fraction of the grid box, as diagnosed from the mean grid box humidity and an assumed subgrid distribution of temperature. In both cases, any water in excess of saturation is precipitated immediately. The GCM precipitation is almost exclusively convective in the tropics and mostly large scale in polar regions; convective precipitation dominates at midlatitudes except in winter. Comparisons of the GCM precipitation with climatological observations have been presented by Hansen et al. [1983] for five GCM years and by Balkanski [1991] for the GCM year used in the ${ }^{210} \mathrm{~Pb}$ simulation. Principal features of the observations are well simulated, but there are regional anomalies. Some of these anomalies as discussed in section 3.

Scavenging of aerosol by convective precipitation is computed in the model as part of the convective mass transport operator; air pumped in wet convective updrafts loses a fraction of its aerosol to deposition before dispersing at the top of the updraft. We call this fraction the scavenging efficiency. Because wet convection in the GISS GCM is always associated with precipitation, we apply the scavenging efficiency to all wet convective events. Field experiments using aerosol tracers indicate scavenging efficiencies ranging from 5 to $100 \%$, with most values close to $100 \%$ [Gatz, 1977]. We adopt here a $50 \%$ aerosol scavenging efficiency in shallow wet convection (extending up to layer 3 , or $\sim 2600 \mathrm{~m}$ altitude) and a $100 \%$ scavenging efficiency in deep wet convection. These values were chosen to optimize the simulation of observed ${ }^{210} \mathrm{~Pb}$ concentrations. Tests indicate that increasing the scavenging efficiency in shallow wet convection to $100 \%$ would decrease mean ${ }^{210} \mathrm{~Pb}$ concentrations in surface air by $10-$ $40 \%$ depending on region, while decreasing the scavenging efficiency to $25 \%$ would increase concentrations by $20-80 \%$ in surface air over the oceans (effect over the continents would be less). Decreasing the scavenging efficiency in deep wet convection to $50 \%$ would increase mean concentrations by 20 $100 \%$ in surface air over the ocean and by $40-140 \%$ in the upper troposphere.

Scavenging by large-scale precipitation cannot be computed in the above way because it is not associated with a convective mass flux in the GCM. We use instead first-order loss operators to describe in-cloud scavenging (rainout) and below-cloud scavenging (washout). Because aerosol is efficiently scavenged from a precipitating cloud over a 4-hour time step, it is important to resolve the areal fraction $F$ of a cloudy grid box that actually experiences large-scale precipitation. We use the parameterization of Giorgi and Chameides [1986]:

$$
F=\frac{F_{\mathrm{o}} Q \Delta t}{L \beta T_{\mathrm{c}}}
$$

with

$$
\beta=\beta_{-}+\frac{Q \Delta t}{L T_{c}}
$$

where $Q\left(\mathrm{~kg} \mathrm{~m}^{-3} \mathrm{~s}^{-1}\right)$ is the mean water condensation rate (largescale precipitation only) in the grid box over the model time $\Delta t=4$ hours, $T_{\mathrm{c}}$ is the duration of precipitation over the time step (here $\left.T_{c}=\Delta t\right), L=0.5 \times 10^{-3} \mathrm{~kg} \mathrm{~m}^{-3}$ is a specified cloud liquid-water content, $\beta\left(\mathrm{s}^{-1}\right)$ is the rate of conversion of cloud water to precipitation, $\beta_{-}=1 \times 10^{-4} \mathrm{~s}^{-1}$ is a minimum value for $\beta$, and $F_{\mathrm{o}}$ is a maximum value for $F$ (here $F_{\mathrm{o}}=1$ ). Values of $Q$ are computed in the model by difference between the large-scale precipitation rates through the bottom and top of the grid box. Similarity between rainout of aerosol and cloud water is assumed [Giorgi and Chameides, 1986], so that $\beta$ represents the first-order rate constant for aerosol loss from the precipitating cloud. The large

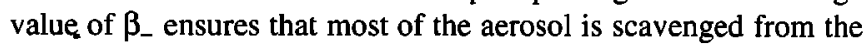
precipitating cloud over a 4-hour time step; the scavenged fraction of aerosol in a grid box is thus largely defined by $F$. We find a median value $F=0.1$ for grid boxes experiencing large-scale precipitation in the GCM, with values exceeding 0.4 in only $10 \%$ of these grid boxes.

A check on the values of $F$ computed in the GCM can be obtained by comparing the resulting frequency distribution of instantaneous precipitation rates to climatological observations. We compute the frequency of precipitation at a given site in the GCM by using the 4-hour time series of mean surface precipitation rates $P$ in the $4^{\circ} \times 5^{\circ}$ grid square, assuming for $F$ the value computed from (1) in the lowest cloudy layer $(Q>0)$ above the surface and further assuming that precipitation within the grid box is spatially random. The probability of precipitation occurring at the site during the 4-hour period is then $F$, and the associated precipitation rate is $P \Delta t / F T_{c}$. For evaluation with observed precipitation frequencies, we must compute $F$ also for convective precipitation, and we use for this purpose equations (1) and (2) with $T_{\mathrm{c}}=2$ hours, $L=2 \times 10^{-3} \mathrm{~kg} \mathrm{~m}^{-3}, \beta_{-}=4.5 \times 10^{-4} \mathrm{~s}^{-1}$, and $F_{\mathrm{o}}=$ 0.3 [Giorgi and Chameides, 1986]. Note that the values of $F$ for convective precipitation are used only to compare simulated and observed precipitation frequencies; they are not used to compute aerosol scavenging in the model. Figure 1 compares simulated precipitation frequencies in the GCM year to climatological observations at 12 temperate sites [Jones and Sims, 1976]. The model gives a credible representation of observations, lending support to the values computed for $F$.

Washout by large-scale precipitation in grid boxes below cloud $(Q \leq 0)$ is computed as a first-order loss process applied to the precipitating fraction of the grid box (defined by the value of $F$ in the lowest cloudy layer overhead). We adopt a washout rate constant of $0.1 \mathrm{~mm}^{-1}$ normalized to the precipitation rate [Dana and Hales, 1976]. For a typical large-scale precipitation rate of 2 $\mathrm{mm} \mathrm{h} \mathrm{h}^{-1}$, the lifetime of aerosol in the precipitating column is 5 hours. Fractional or total evaporation of precipitation in a grid 


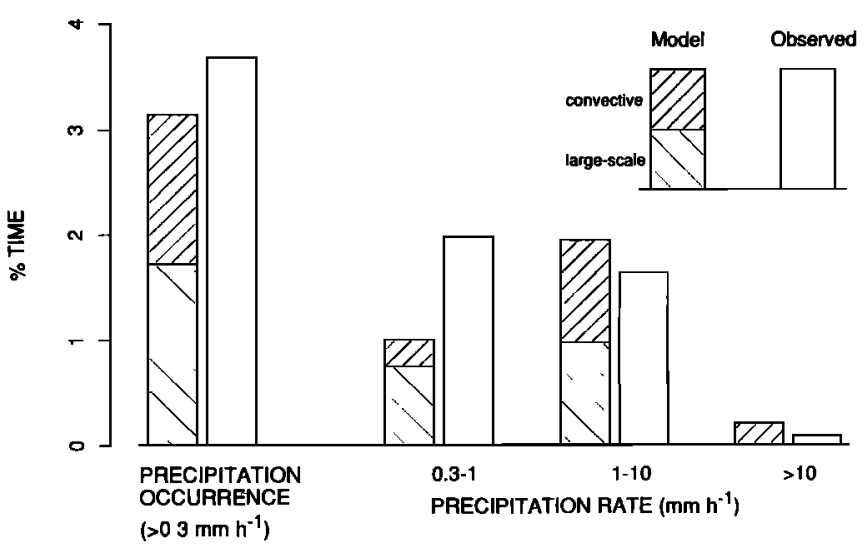

Fig. 1. Frequencies of precipitation occurrence and instantaneous precipitation rates at 12 temperate sites for which climatological observations are available [Jones and Sims, 1976]. The Figure shows the percentage of the time precipitation occurs at a given rate, averaged over all sites. The 12 sites are Reading and Preston, England; Paris, France; Freiburg and Koblenz, Germany; Okinawa, Japan; Woody Island, Alaska; Seattle, Washington; Bismarck, North Dakota; Urbana, Illinois; Franklin, North Carolina; and Island Beach, New Jersey.

box below cloud releases the corresponding fraction of the precipitating aerosol flux into the grid box.

Dry deposition of ${ }^{210} \mathrm{~Pb}$ out of the lowest model layer is computed using a deposition velocity expressed as the inverse of the sum of an aerodynamic resistance and a surface resistance placed in series [Wesely et al., 1985; Voldner et al., 1986]. The aerodynamic resistance is computed for the air column extending from the surface to the midpoint of the lowest layer $(-250 \mathrm{~m})$ as a function of the friction velocity $u_{*}$, the Monin-Obukhov length $\Lambda$, and a roughness height dependent on surface type and season. Values of $u_{*}$ and $\Lambda$ over land are estimated from a PasquillGifford parameterization as a function of GCM wind speed, insolation, cloud cover, and roughness height [Seinfeld, 1986]. Over water, a neutral atmosphere is assumed at all times $(\Lambda \rightarrow \infty)$, and $u_{*}$ is calculated from the local wind speed and roughness height. The surface resistance to deposition is calculated as a function of $u_{m}$ and $\Lambda$ using parameterizations given by Wesely et al. [1985] and Hicks et al. [1989] for sulfate deposition to grassland and forest. For want of better information, we extend

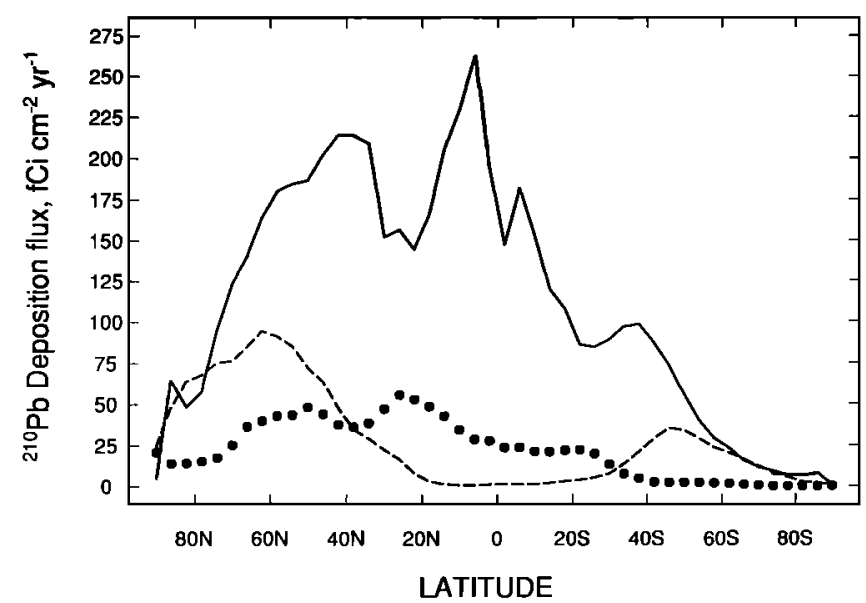

Fig. 2. Zonal mean deposition fluxes of ${ }^{210} \mathrm{~Pb}$ in the model contributed by convective precipitation (solid line), large-scale precipitation (dashed line), and dry processes (dotted line). Values are yearly averages. these parameterizations to all surfaces. The resulting global mean dry deposition velocities are $0.05 \mathrm{~cm} \mathrm{~s}^{-1}$ over oceans and $0.2 \mathrm{~cm}$ $\mathrm{s}^{-1}$ over land.

We find in the model that scavenging in convective updrafts represents $74 \%$ of the global ${ }^{210} \mathrm{~Pb}$ sink and dominates at all latitudes except near the poles (Figure 2). Scavenging by largescale precipitation represents only $12 \%$ of the global sink and is probably overpredicted at high northern latitudes, as discussed below. Dry deposition represents $14 \%$ of the global sink. Our results can be compared to the simulation of Feichter et al. [1991], which used a first-order rainout scheme to compute scavenging by convective precipitation; the global sink for ${ }^{210} \mathrm{~Pb}$ in that simulation was dominated by large-scale precipitation (61\%) followed by convective precipitation $(26 \%)$ and dry deposition (13\%). The first-order rainout scheme underestimates scavenging by convective precipitation, as pointed out above.

\section{COMParison With OBSERVATIONS}

The model simulation was conducted for 15 months, starting from low ${ }^{222} \mathrm{Rn}$ and ${ }^{210} \mathrm{~Pb}$ concentrations as initial conditions. The first 3 months are used for initialization, and we present results from the last 12 months. Figures $3 a$ to $3 c$ show the simulated global distributions of ${ }^{222} \mathrm{Rn}$ and ${ }^{210} \mathrm{~Pb}$ in January and July: concentrations in surface air and at $6-\mathrm{km}$ altitude and zonal mean concentrations as a function of latitude and altitude. The units are picocuries per standard cubic meter $\left(\mathrm{m}^{3} \mathrm{STP}\right)$ of air for ${ }^{222} \mathrm{Rn}\left(1 \mathrm{pCi} / \mathrm{m}^{3} \mathrm{STP}=6.6 \times 10^{-22} \mathrm{vol} / \mathrm{vol}\right)$ and femtocuries per $\mathrm{m}^{3}$ STP of air for ${ }^{210} \mathrm{~Pb}\left(1 \mathrm{fCi} / \mathrm{m}^{3} \mathrm{STP}=3.70 \times 10^{-5} \mathrm{~Bq} / \mathrm{m}^{3} \mathrm{STP}=\right.$ $1.41 \times 10^{-21} \mathrm{~mol}$ of ${ }^{210} \mathrm{~Pb}$ per mol of air).

Our discussion here will be limited to the troposphere. The GCM resolves the stratosphere with only one to three layers and thus cannot provide a realistic description of cross-tropopause mass transport or stratospheric circulation. After 15 months of simulation we find that ${ }^{210} \mathrm{~Pb}$ in the model stratosphere is near steady state, with concentrations averaging $17 \mathrm{fCi} / \mathrm{m}^{3} \mathrm{STP}$ at 14-19 $\mathrm{km}$ and $24 \mathrm{fCi} / \mathrm{m}^{3}$ STP at 19-32 km. In comparison, observations indicate a mean concentration of $8 \mathrm{fCi} / \mathrm{m}^{3} \mathrm{STP}$ at $15-19 \mathrm{~km}$ [Krey, 1975, as cited by Lambert et al., 1982]. The overprediction of ${ }^{210} \mathrm{~Pb}$ concentrations in the stratosphere implies that air entering the stratosphere contains too much ${ }^{222} \mathrm{Rn}$. Injection of ${ }^{222} \mathrm{Rn}$ into the stratosphere during deep convective storms could be overestimated owing to the nonentraining nature of wet convection in the GISS GCM. The consequence for model results in the troposphere is negligible because the stratospheric inventory of ${ }^{210} \mathrm{~Pb}$ is small (only $1 \%$ of total atmospheric ${ }^{210} \mathrm{~Pb}$ in the model is produced above the tropopause).

The GISS GCM is intended to simulate a typical meteorological year rather than a specific year; comparison of model results with observations must therefore rely on seasonal statistics rather than on data for any particular day. Figures $4 a$ and $4 b$ compare simulated and observed yearly mean concentrations and total deposition fluxes at sites around the world (85 sites for concentrations, 55 sites for fluxes; Figures $5 a$ and $5 b$ ). The model captures $63 \%$ of the spatial variance of concentrations and $34 \%$ of the variance of fluxes (54\% if the four sites with highest fluxes are excluded). We define the percent model bias as

$$
\text { bias }=100 \frac{C_{\mathrm{s}}-C_{\mathrm{o}}}{\max \left(C_{0}, C_{\mathrm{s}}\right)}
$$

where $C_{\mathrm{S}}$ and $C_{\mathrm{O}}$ are the simulated and observed ${ }^{210} \mathrm{~Pb}$ concentrations, respectively. We find negligible mean bias in the 

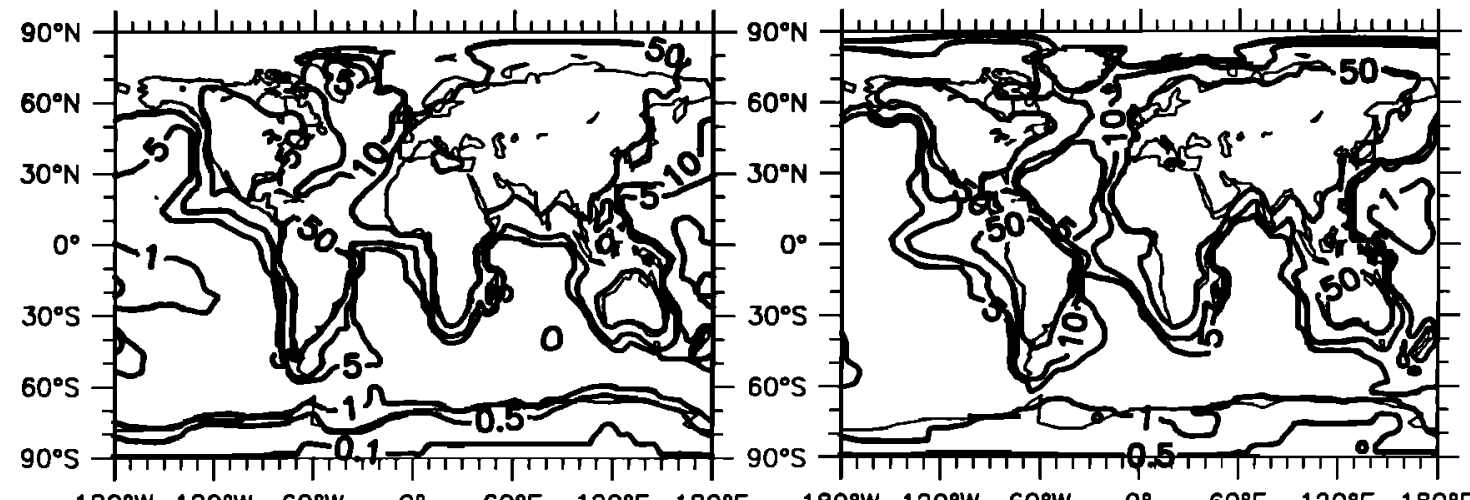

$180^{\circ} \mathrm{W} \quad 120^{\circ} \mathrm{W} \quad 60^{\circ} \mathrm{W} \quad 0^{\circ} \quad 60^{\circ} \mathrm{E} \quad 120^{\circ} \mathrm{E} \quad 180^{\circ} \mathrm{E} \quad 180^{\circ} \mathrm{W} \quad 120^{\circ} \mathrm{W} \quad 60^{\circ} \mathrm{W} \quad 0^{\circ} \quad 60^{\circ} \mathrm{E} \quad 120^{\circ} \mathrm{E} \quad 180^{\circ} \mathrm{E}$
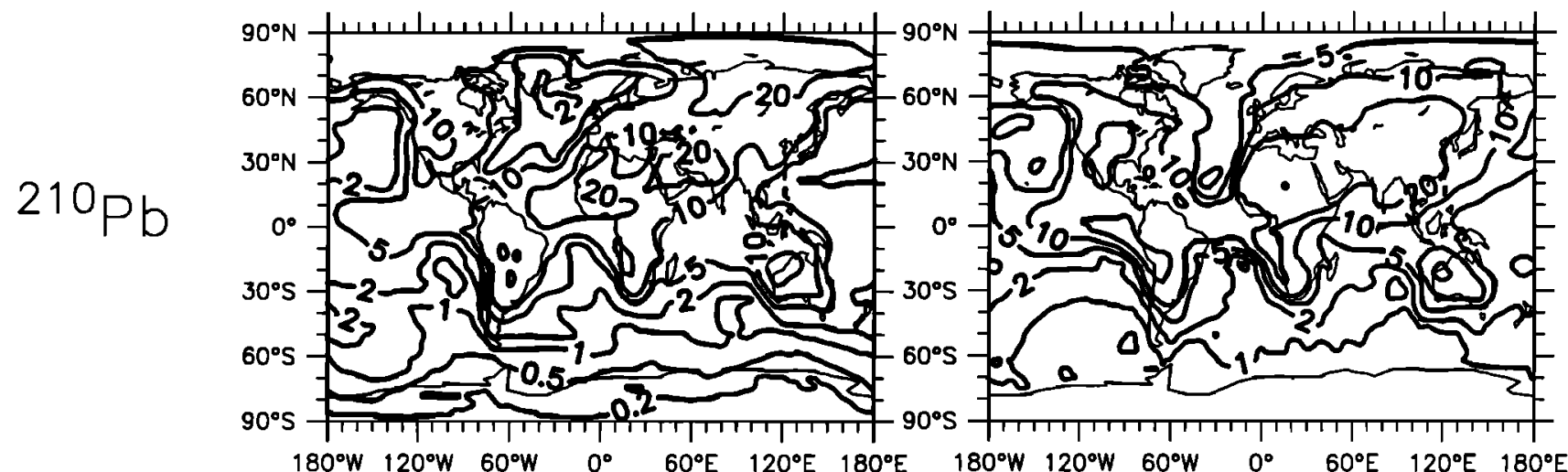

Fig. 3a. Monthly mean concentrations of ${ }^{222} \mathrm{Rn}\left(\mathrm{pCi} / \mathrm{m}^{3} \mathrm{STP}\right)$ and ${ }^{210} \mathrm{~Pb}\left(\mathrm{fCi} / \mathrm{m}^{3} \mathrm{STP}\right)$ in surface air in the model for January and July.
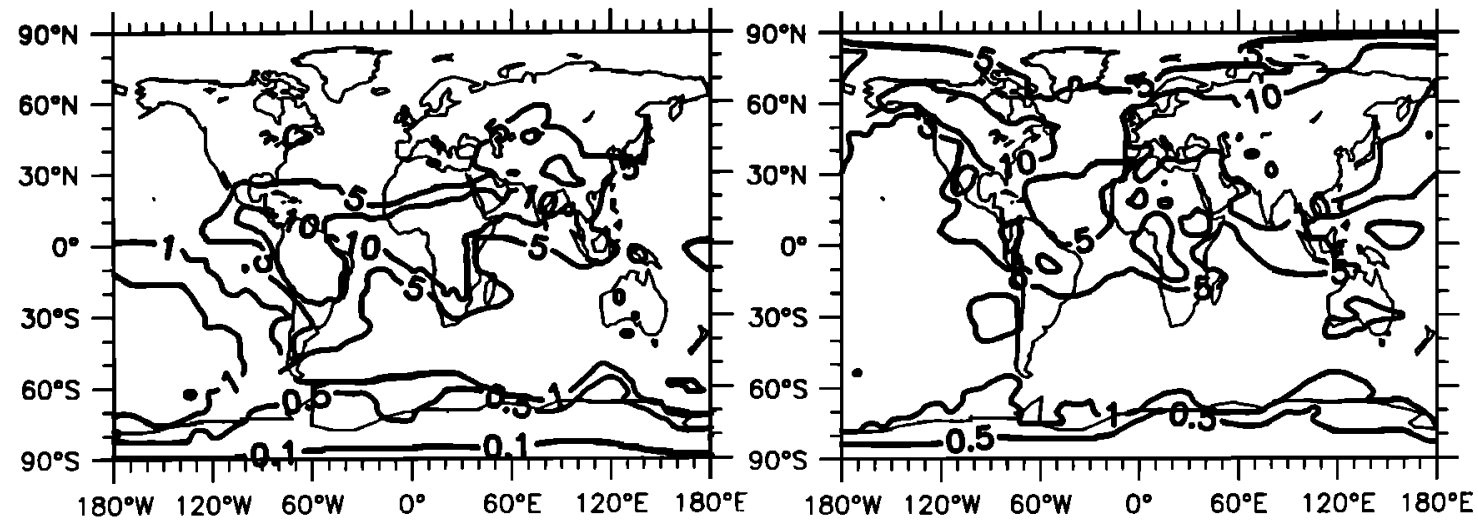

$180^{\circ} \mathrm{W} 120^{\circ} \mathrm{W} \quad 60^{\circ} \mathrm{W} \quad 0^{\circ} \quad 60^{\circ} \mathrm{E} \quad 120^{\circ} \mathrm{E} \quad 180^{\circ}$

$210 \mathrm{~Pb}$
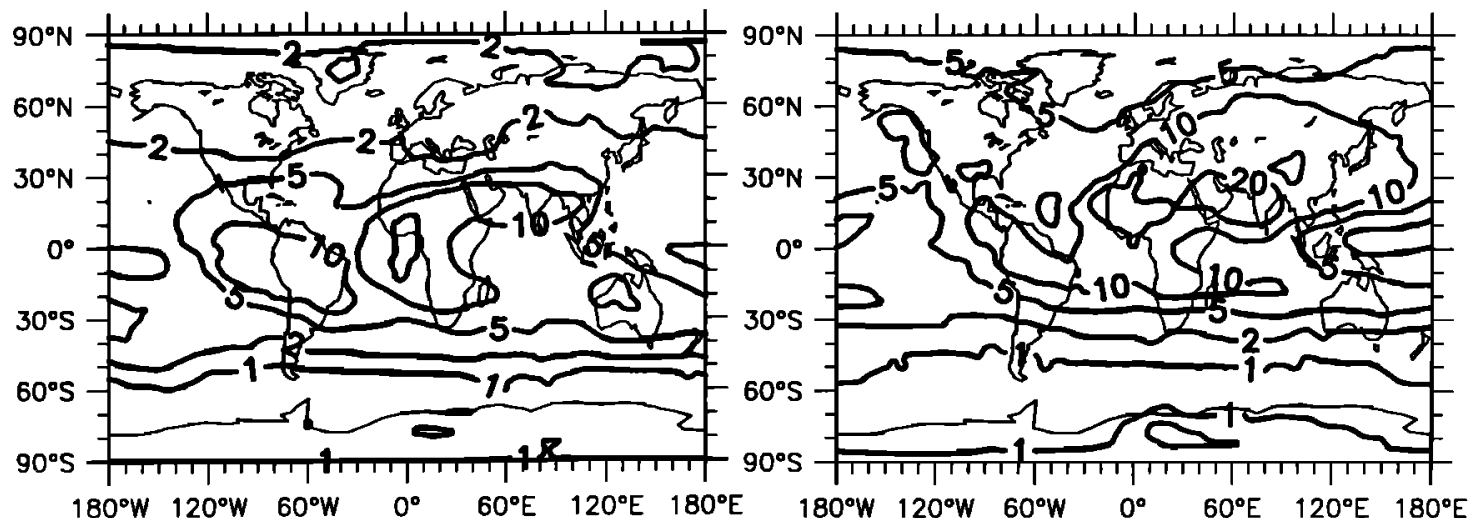

Fig. $3 b$. Monthly mean concentrations of ${ }^{222} \mathrm{Rn}\left(\mathrm{pCi} / \mathrm{m}^{3} \mathrm{STP}\right)$ and ${ }^{210} \mathrm{~Pb}\left(\mathrm{fCi} / \mathrm{m}^{3} \mathrm{STP}\right)$ at $6-\mathrm{km}$ altitude in the model for January and July. 
JANUARY
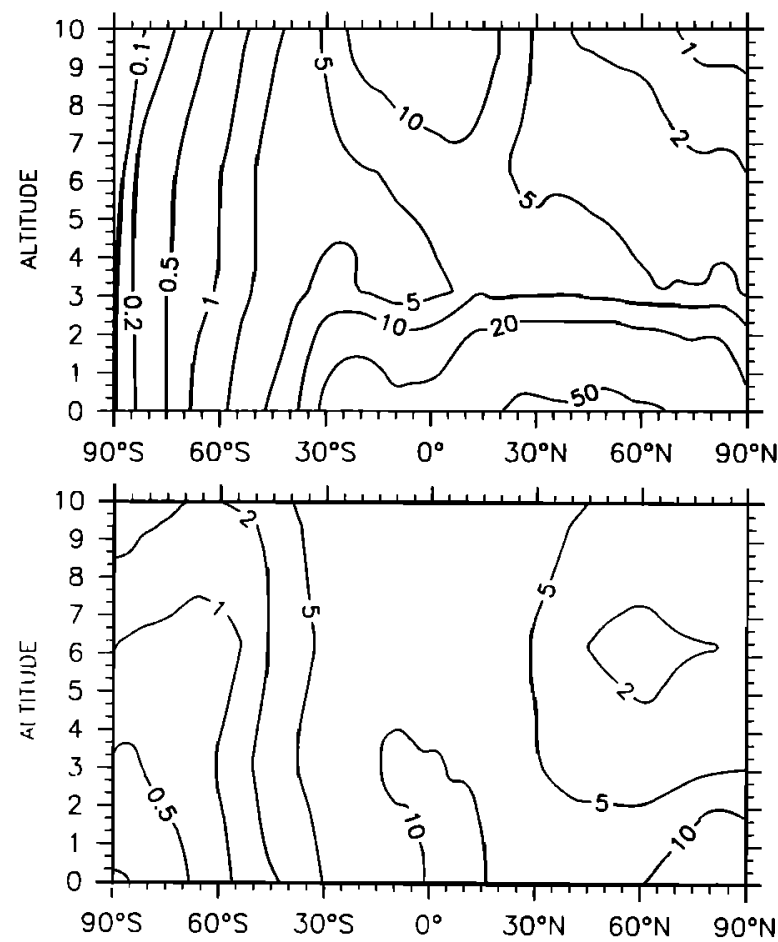

JULY
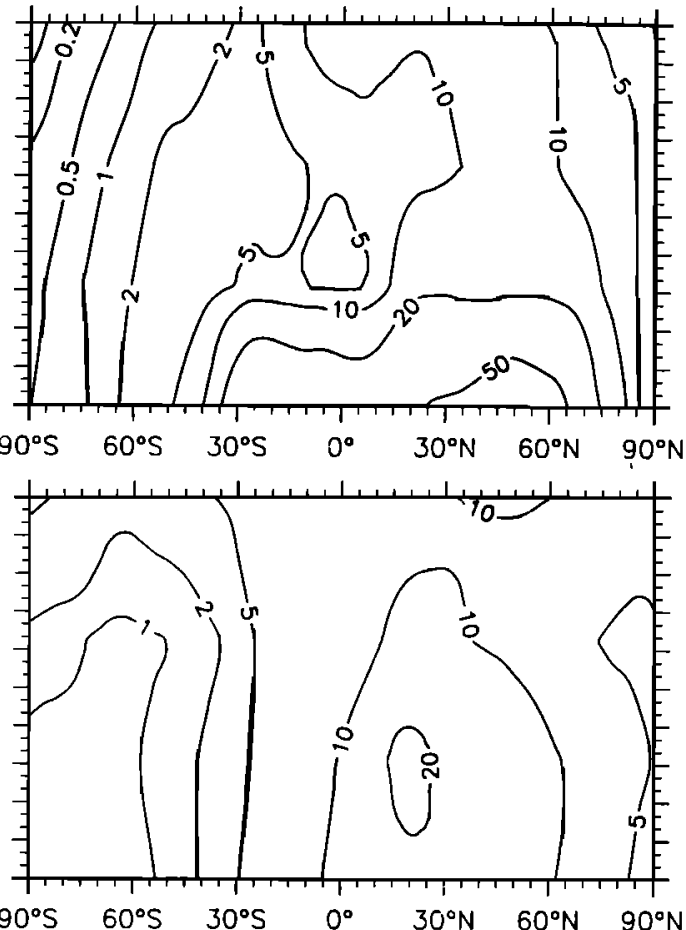

Fig. 3c. Zonal mean concentrations of ${ }^{222} \mathrm{Rn}\left(\mathrm{pCi} / \mathrm{m}^{3} \mathrm{STP}\right)$ and ${ }^{210} \mathrm{~Pb}\left(\mathrm{fCi} / \mathrm{m}^{3} \mathrm{STP}\right)$ as a function of altitude and latitude in the model for January and July.

simulation of fluxes $(-2 \%)$, providing a check on the magnitude of the ${ }^{222} \mathrm{Rn}$ source. We also find negligible mean bias in the simulation of concentrations $(+3 \%)$, lending support to the computation of aerosol residence times.

The scatter in Figure 4 indicates, however, a number of regional discrepancies between model and observations that may reflect in part variability of ${ }^{222} \mathrm{Rn}$ emission but also point to anomalies in

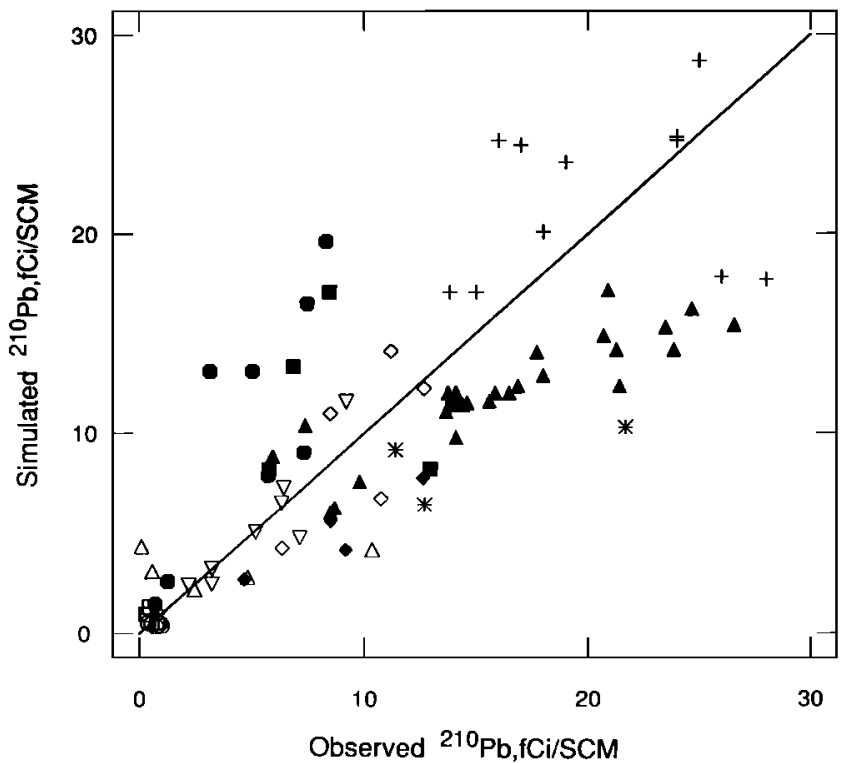

Fig. $4 a$. Scatterplot of simulated versus observed yearly mean ${ }^{210} \mathrm{~Pb}$ concentrations at 85 sites around the world for which at least one full year of observations is available. The 1:1 line is also shown. Site locations and references are given in Figure $5 a$.
GCM precipitation. We present in Figure 6 a more detailed evaluation of the model using monthly mean concentrations.

Figure $6 a$ compares simulated and observed concentrations at North American and Arctic sites. The model does not capture the observed winter maximum at high northern latitudes which is due to long-range boundary layer transport of Eurasian air over the

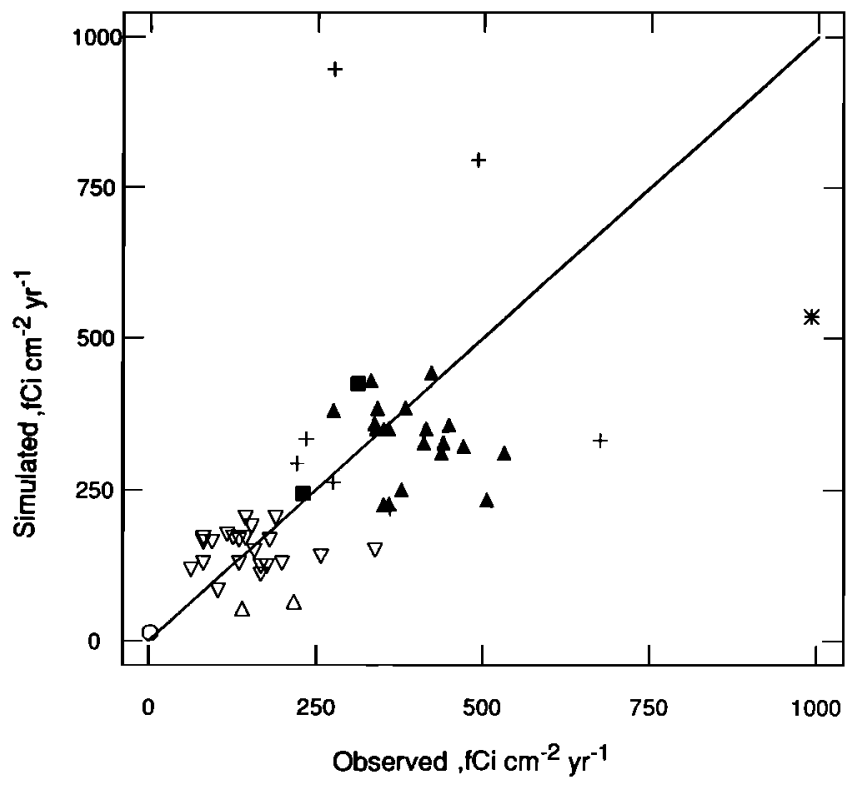

Fig. $4 b$. Scatterplot of simulated versus observed yearly mean total deposition fluxes of ${ }^{210} \mathrm{~Pb}$ at 55 sites around the world for which at least one full year of observations is available. The 1:1 line is also shown. The measurements are from open buckets and soil inventories. Site locations and references are given in Figure $5 b$. 


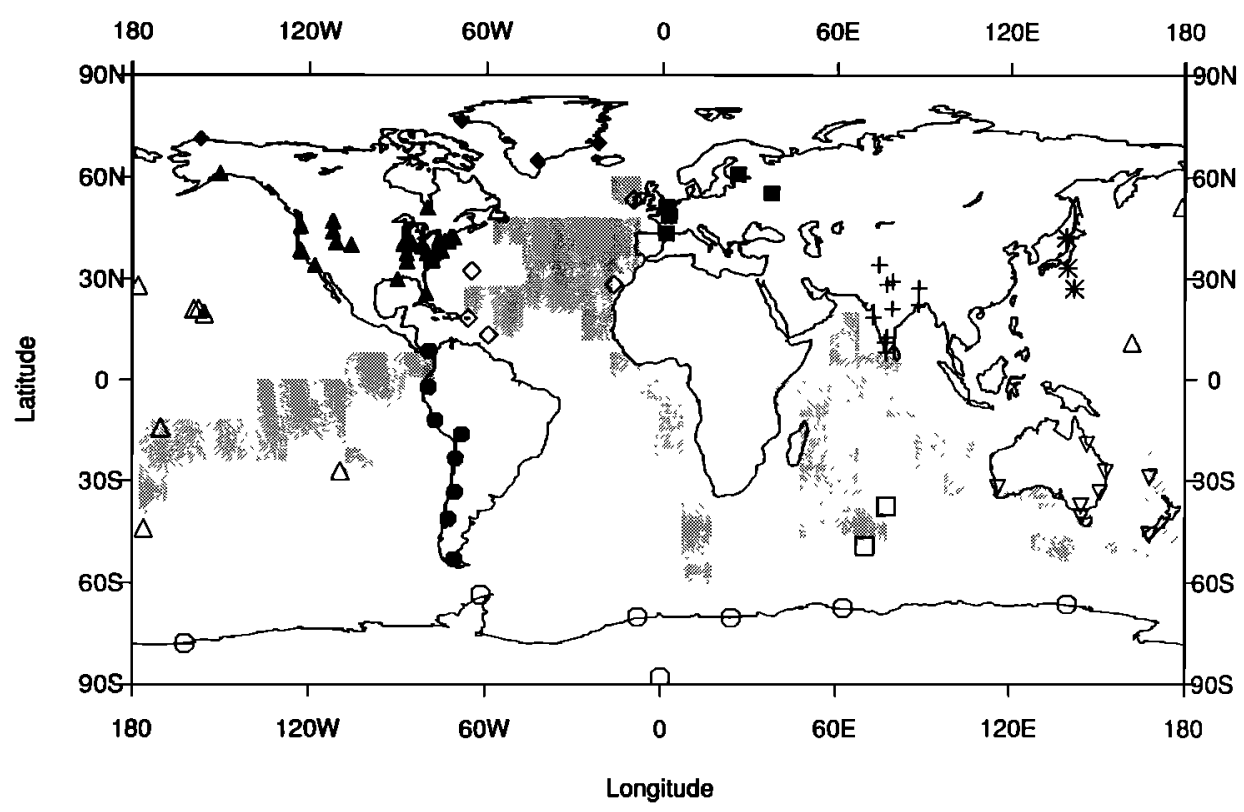

Fig. 5a. Sites of ${ }^{210} \mathrm{~Pb}$ air concentration measurements. The symbols identify 88 sites; 3 of these (Midway, Oahu, and Enewetak) have less than 1 year of observations and are therefore not included in Figure $4 a$ (they are included in Figure 6c). Closed diamonds, Arctic (DJ93, F88); closed triangles, North America (F88, GT86, GT93, L82); closed squares, Europe (L82); closed octagons, South America (F88, L82); plus signs, India (M80); asterisks, Japan (T88); open inverted triangles, Oceania (B72, F88, T90); open diamonds, north Atlantic (F88, GT93); open triangles, Pacific (F88, L82, T90); open squares, Indian Ocean (L82); open octagons, Antarctica (F88, L82, W88); shaded areas, ship measurements (L82). Reference code: B72 Bonnyman et al. [1972]; DJ93 Dibb and Jaffrezo [1993]; F88 Feely et al. [1988] and references therein; GT86 Graustein and Turekian [1986]; GT93 W.C. Graustein and K.K. Turekian, unpublished data; L82 Lambert et al. [1982] and references therein; M80 Mishra et al. [1980]; T88 Tsunogal et al. [1988]; T90 Turekian et al. [1990]; W88 Wagenbach et al. [1988].

Arctic with little precipitation along its trajectory [Barrie, 1986] (the Dye 3 site on the Greenland plateau is isolated from this Eurasian pollution, perhaps because of its high elevation). We have previously found in simulations of ${ }^{85} \mathrm{Kr}$ and $\mathrm{CO}$ that the model reproduces well the wintertime transport of pollution from Eurasia to the Arctic [Jacob et al., 1987; J. A. Logan, personal communication, 1993], but ${ }^{210} \mathrm{~Pb}$ is scavenged from the model Eurasian plume because of anomalously high precipitation in the Arctic winter in the GCM [Hansen et al., 1983]. Figure 6a shows that ${ }^{210} \mathrm{~Pb}$ concentrations at United States sites in winter also tend to be underpredicted, possibly because mixing depths in that season are too shallow to be resolved by the model.

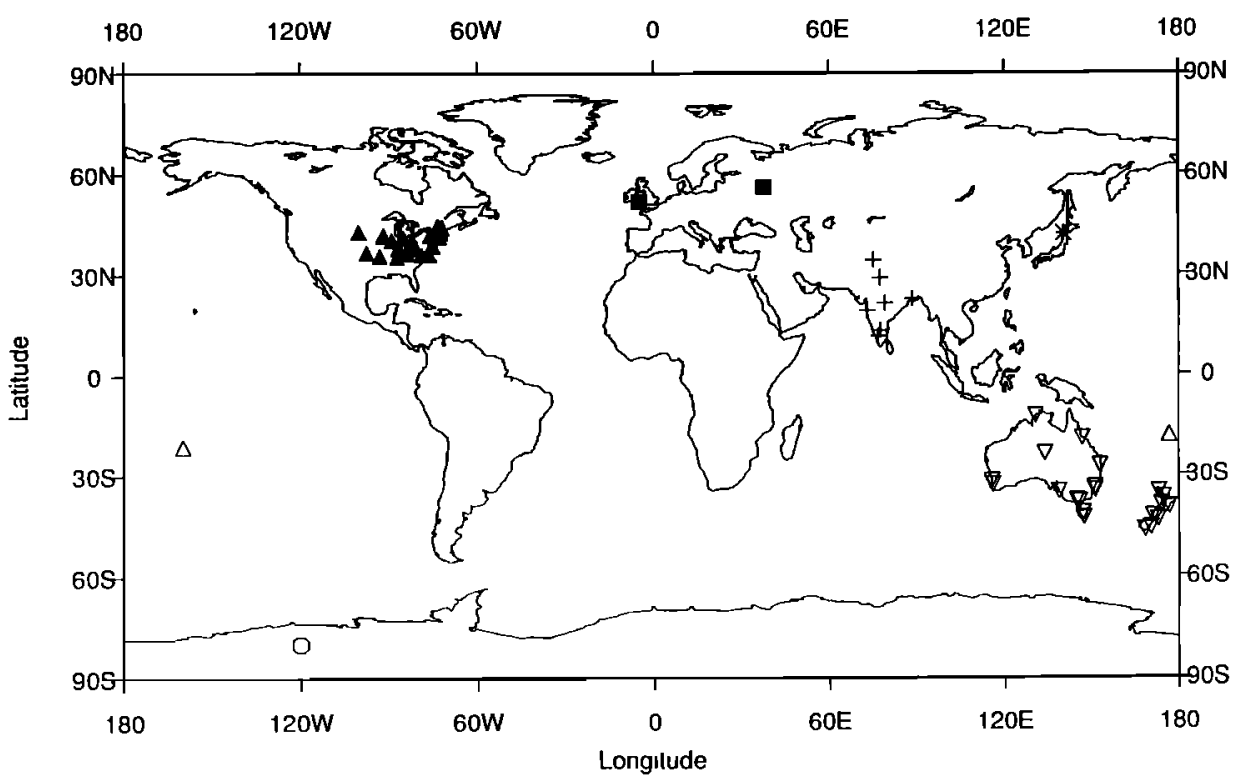

Fig. 5b. Sites of ${ }^{210} \mathrm{~Pb}$ deposition flux measurements. The data are from Turekıan et al. [1977] and references therein, with additional North American data from Olsen et al. [1985], Graustein and Turekian [1986], and Todd et al. [1989]. Symbols are as in Figure $5 a$. 

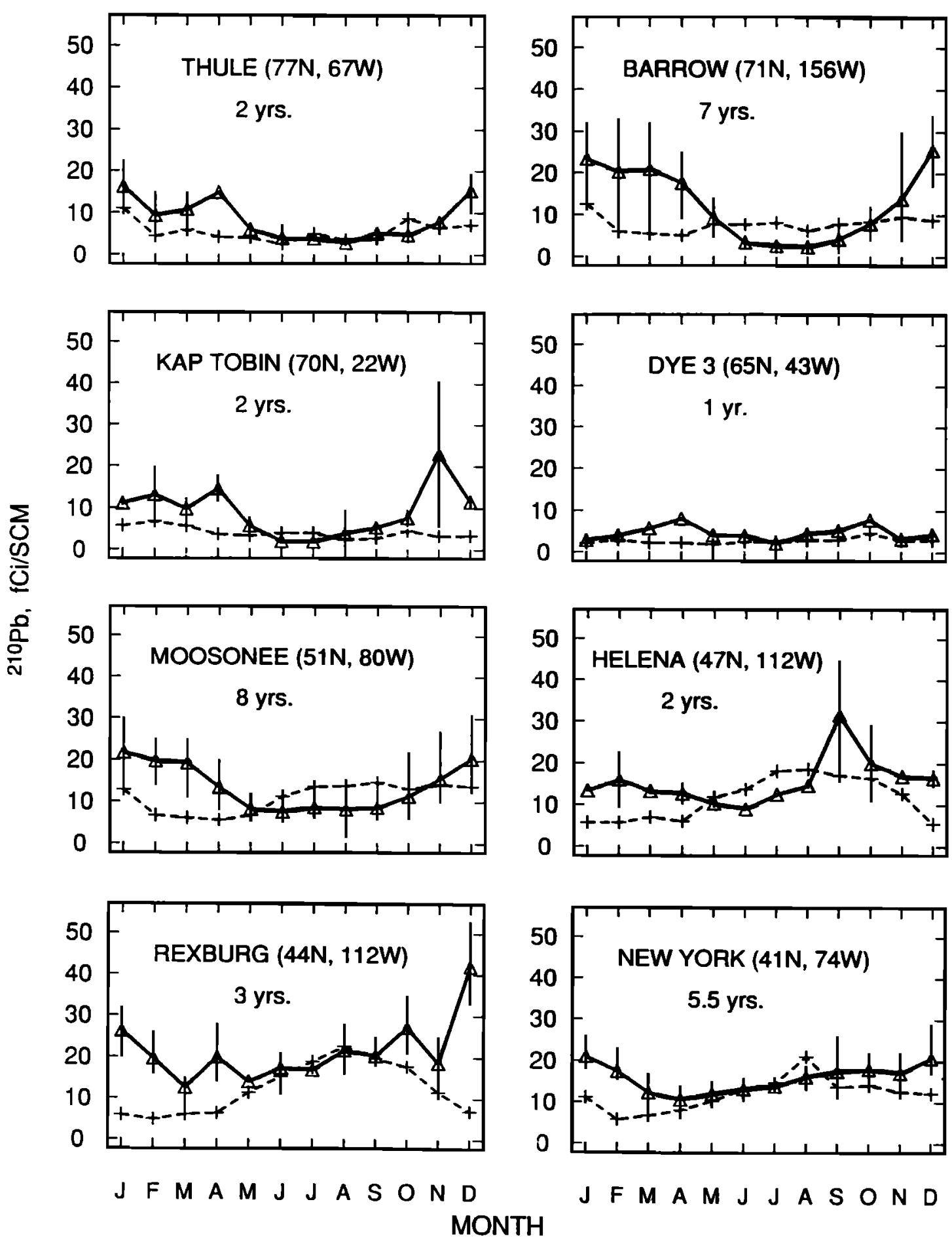

Fig. 6a. Seasonal variations of simulated (dashed lines) and observed (solid lines) monthly mean ${ }^{210} \mathrm{~Pb}$ concentrations at Arctic and North American sites. Interannual ranges in the observations are shown for sites for which several years of data are available (the number of years of data is given in the figure). Observations are from Dibb and Jaffrezo [1993] for Dye 3 and Feely et al. [1988] for other sites.

Results for north Atlantic sites are shown in Figure $6 b$. Concentrations at Bermuda are underpredicted, especially in winter, because of excessive GCM precipitation off the east coast of North America. Simulated concentrations at Izania (Canary Islands, $2400 \mathrm{~m}$ altitude) peak in October, when a weakening of the GCM Azores High allows advection of the Saharan plume to the Canary Islands. The plume is usually deflected to the south, both in the model and in the observations [Sancho et al., 1992]. The July-September maximum in the observations at Izania probably reflects the same mechanism as in the model but occurs 1-3 months earlier [Sancho et al., 1992]. The summertime maximum at Barbados in the model is caused by subsidence of the Saharan plume over the Caribbean following its transport over the Atlantic in the middle troposphere. It is consistent with the 

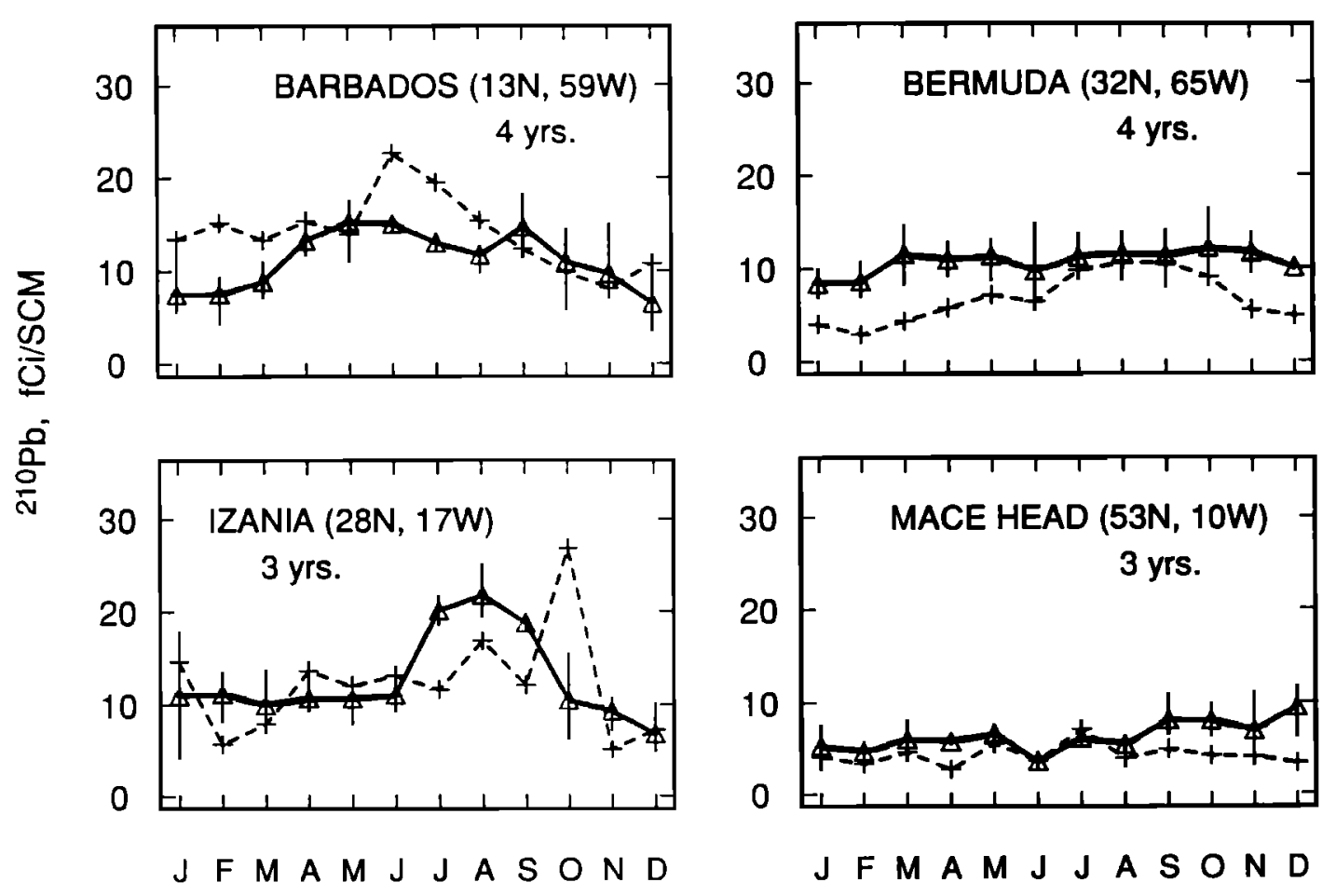

\section{MONTH}

Fig $6 b$. Seasonal variations of simulated (dashed lines) and observed (solid lines) monthly mean ${ }^{210} \mathrm{~Pb}$ concentrations at north Atlantic sites. Interannual ranges in the observations are shown. Observations are from W.C. Graustein and K.K. Turekian (unpublished data, 1993).

observed summer maximum of Saharan dust influence at Barbados [Prospero and Nees, 1986]. The observations for ${ }^{210} \mathrm{~Pb}$ at Barbados show, however, only a weak summer maximum, perhaps because emission of ${ }^{222} \mathrm{Rn}$ from the Sahara is weak $(\mathrm{H}$. Dorr, personal communication, 1993). Concentrations at Mace Head (west coast of Ireland) are lower than at other north Atlantic sites and show little seasonality, either in the model or in the observations.

Results for Pacific and Antarctic sites are shown in Figure $6 c$. Good agreement between model and observations is found in the southern hemisphere, but simulated concentrations over the north Pacific are too low; in particular, the model does not capture the observed winter-spring maximum that is due to Asian influence [Merrill, 1990]. We have previously found in simulations of ${ }^{222} \mathrm{Rn}$ and $\mathrm{CO}$ that the model reproduces the observed strength and seasonality of Asian influence over the north Pacific [Balkanski et al., 1992; J.A. Logan, personal communication, 1993]. However, ${ }^{210} \mathrm{~Pb}$ is scavenged from the Asian plume in the model because of anomalously frequent wet convection off the coast of Japan.

Mean ${ }^{210} \mathrm{~Pb}$ concentrations measured over the oceans from ships have been compiled by Lambert et al. [1982] on a $10^{\circ} \times 10^{\circ}$ grid. The compilation includes 943 samples from 24 ship cruises (shaded areas in Figure 5). The model captures only $24 \%$ of the observed spatial variance of concentrations at the $10^{\circ} \times 10^{\circ}$ scale, certainly in part because the observations are sparse. Figure 7 shows the data averaged over $30^{\circ}$-wide latitudinal bands; both model and observations indicate higher concentrations in the northern hemisphere than in the south and higher concentrations in the tropics than at extratropical latitudes. The maximum in the northern tropics reflects strong continental influence over the
Atlantic and Indian oceans, where most of the observations were collected. The model overpredicts this maximum.

Measurements of ${ }^{210} \mathrm{~Pb}$ concentrations at altitude are few, scattered, and often affected by sample contamination [Lambert et $a l ., 1982]$. The most extensive and widely used data are from 11 flights over the west central United States by Moore et al. [1973]. Figure 8 compares the measured profiles, grouped by season, to the model means for the corresponding locations and months. Simulated concentrations are consistent with the observations except at high altitude $(8-9 \mathrm{~km})$, where the model is about a factor of 3 too high. Unpublished aircraft measurements taken recently by J.E. Dibb offshore from Asia indicate ${ }^{210} \mathrm{~Pb}$ concentrations in the upper troposphere that are higher than those observed by Moore et al. [1973] and more consistent with the values found in our model.

A striking feature of model results is the weak gradient of ${ }^{210} \mathrm{~Pb}$ concentrations between the continental mixed layer and the free troposphere. Simulated concentrations at $6-\mathrm{km}$ altitude are $\sim 50 \%$ of continental mixed-layer values over much of the northern hemisphere in summer, and over large areas of the tropics year around (Figure $3 b$ ). This result is consistent with the few observations available for the free troposphere [Moore et al., 1973; J.E. Dibb, personal communication, 1993]. In contrast, total aerosol concentrations measured from aircraft over continental regions typically show an order of magnitude decrease from the mixed layer to the free troposphere [Gregory et al., 1990, 1992]. An explanation is that convective precipitation scavenges aerosols and soluble aerosol precursors but not ${ }^{222} \mathrm{Rn}$; ${ }^{222} \mathrm{Rn}$ pumped in convective updrafts supplies a source of ${ }^{210} \mathrm{~Pb}$ at high altitudes where precipitation is infrequent. The importance of wet convection as a mechanism for rapid transport of insoluble tracers 

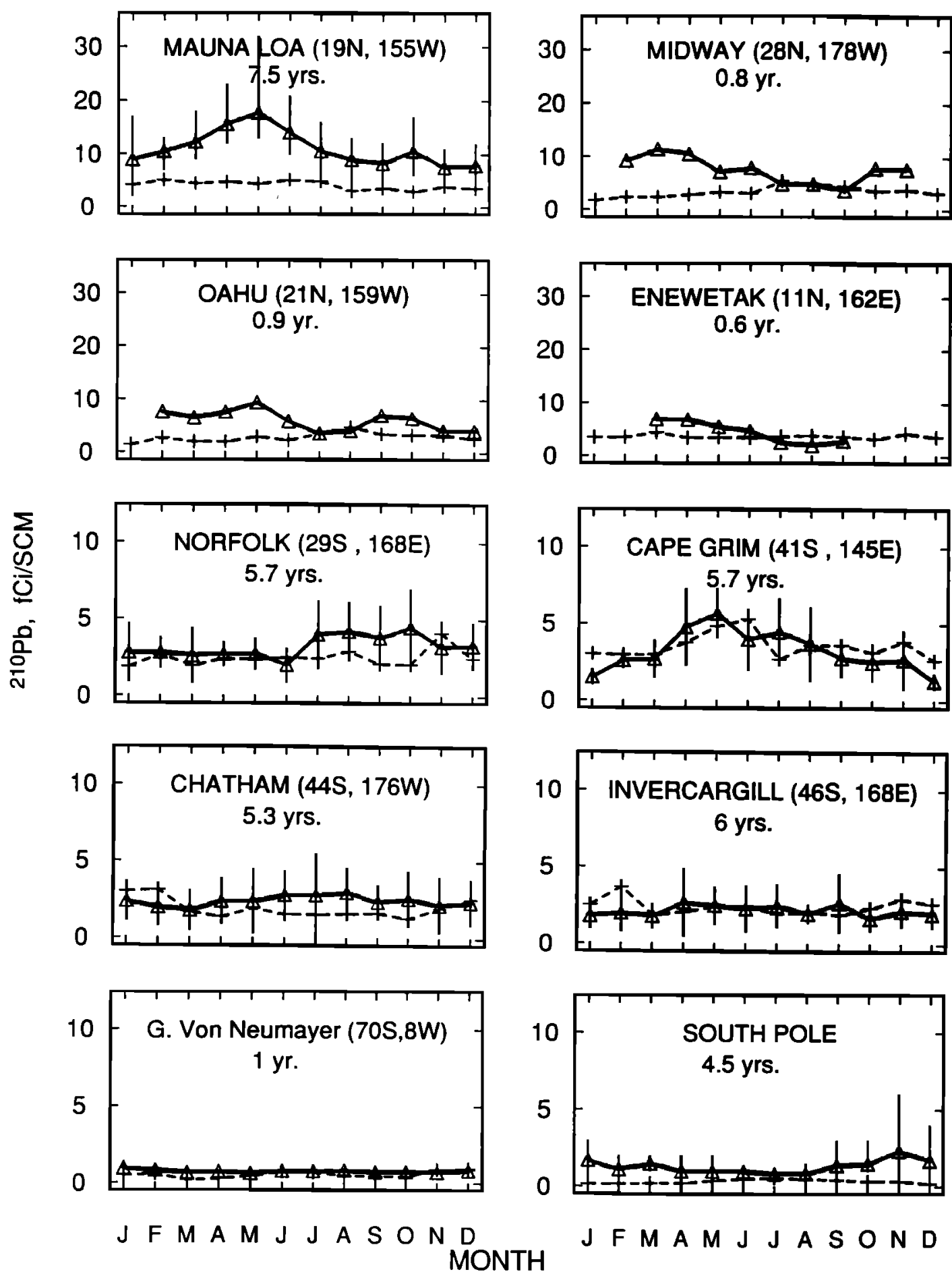

J F M A M J J A S O N D

Fig. $6 c$. Seasonal variations of simulated (dashed lines) and observed (solid lines) monthly mean ${ }^{210} \mathrm{~Pb}$ concentrations at Pacific and Antarctic sites. Interannual ranges in the observations are shown when several years of data are available. Note the difference in scale between northern and southern hemispheres. Observations are from Wagenbach et al. [1988] for G. Von Neumayer; Turekian et al. [1990] for Midway, Oahu, and Enewetak; and Feely et al. [1988] for other sites.

to high altitudes has been pointed out before [Chatfield and Crutzen, 1984; Dickerson et al., 1987; Kritz et al., 1990]. It appears that ${ }^{210} \mathrm{~Pb}$ should not be viewed as a generic tracer of continental aerosols. We may, however, draw an analogy between ${ }^{210} \mathrm{~Pb}$ and nitrate, for which the precursor $\mathrm{NO}_{\mathrm{x}}$ is sparingly soluble. Long-range transport at high altitudes of nitrate of continental origin followed by subsidence over the oceans would explain the strong correlation observed between ${ }^{210} \mathrm{~Pb}$ and nitrate at Samoa and Barbados [Savoie et al., 1989, 1992].

\section{AERosol Residence Times}

We define the residence time of ${ }^{210} \mathrm{~Pb}$ aerosol in the tropospheric column as $\tau=\mathrm{C} / \Phi$, where $\mathrm{C}$ is the ${ }^{210} \mathrm{~Pb}$ column 


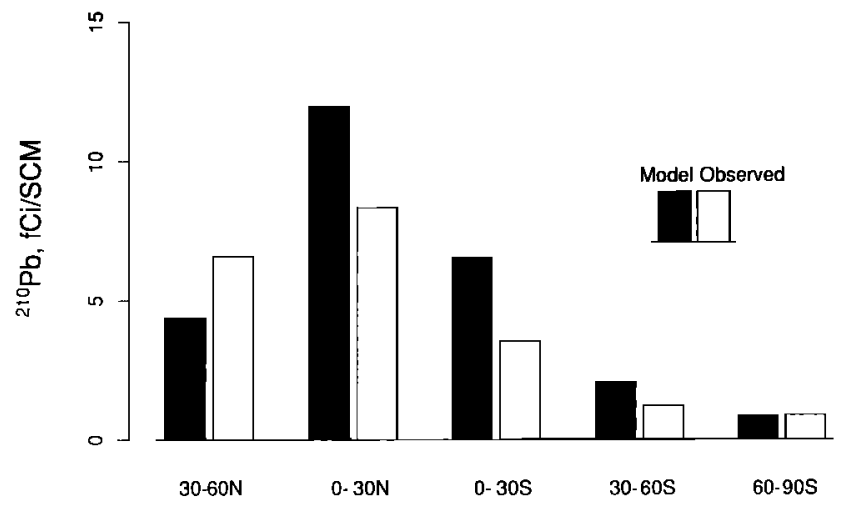

LATITUDE

Fig. 7. Simulated and observed concentrations of ${ }^{210} \mathrm{~Pb}$ in surface air over the oceans as a function of latitude. The observations represent 943 individual measurements from 24 ship cruises covering the shaded area shown in Figure 5 and averaged over $30^{\circ}$-wide latitudinal bands. The model results are monthly means for the locations of the measurements averaged over the same latitude bands.

extending from the surface up to the model layer just below the tropopause, and $\Phi$ is the deposition flux out of the column. Figure 9 shows the mean variation of $\tau$ with latitude in the model for January and July; tropopause heights used to compute $\tau$ were derived from monthly mean GCM temperature profiles as a function of latitude. High values of $\tau$ are found in the southern tropics where a relatively large fraction of the ${ }^{210} \mathrm{~Pb}$ is produced at high altitudes, as discussed above, and eventually subsides over dry regions. Residence times at southern midlatitudes are particularly short (about 5 days) because of frequent precipitation. Residence times at northern midlatitudes vary from about 5 days in winter to 10 days in summer, reflecting the seasonality in convection. Moore et al. [1973] previously estimated a tropospheric residence time of 8 days for ${ }^{210} \mathrm{~Pb}$ over the west central United States, based on radioactive equilibrium of ${ }^{210} \mathrm{~Pb}$ with its short-lived daughters. Our results are consistent with that estimate. The data of Moore et al. [1973] show no evidence for a seasonal dependence of residence time, but their standard deviations are large.

Global mean values of $\tau$ computed in the model are 8.8 days in January and 10.5 days in July. In comparison, Lambert et al. [1982] estimated a global mean $\tau=6.5$ days by using atmospheric inventories of ${ }^{222} \mathrm{Rn}$ and ${ }^{210} \mathrm{~Pb}$ extrapolated from observations and computing the ${ }^{210} \mathrm{~Pb}$ deposition sink to balance ${ }^{222} \mathrm{Rn}$ decay. The longer residence time in our model reflects a higher ${ }^{210} \mathrm{~Pb}$ inventory, due principally to higher concentrations in the tropics. Lambert et al. [1982] estimated ${ }^{210} \mathrm{~Pb}$ columns in the tropics by extrapolating the data of Moore et al. [1973] taken over the United States (Figure 8), but our model results indicate that ${ }^{210} \mathrm{~Pb}$ columns in the tropics are substantially higher than those at northern midlatitudes because of more frequent convective transport of ${ }^{222} \mathrm{Rn}$ (Figure $3 c$ ).

The dependence of aerosol residence time on altitude is of particular interest in terms of assessing the potential for longrange transport. The atmospheric residence time $\tau_{\mathrm{z}}$ of an aerosol at altitude $z$ can be defined in a number of ways. Ehhalt [1973] used as definition $\tau_{\mathrm{z}}=C_{\mathrm{z}} / \Phi$, where $C_{\mathrm{z}}$ is the aerosol column extending from the surface to $z$, and reported values for $\tau_{\mathrm{z}}$ ranging from 5 days at $2-\mathrm{km}$ altitude to 25 days at $10 \mathrm{~km}$ for ${ }^{137} \mathrm{Cs}$ bomb debris over Nebraska. Moore et al. [1973] defined $\tau_{\mathrm{z}}$ as the age of the ${ }^{210} \mathrm{~Pb}$ aerosol at altitude $z$, based on radioactive equilibrium of ${ }^{210} \mathrm{~Pb}$ with its daughters; they found values of 4 days or less in the lower troposphere nd 6-9 days in the upper troposphere over the west central U.S. Giorgi and Chameides [1986] defined $\tau_{\mathrm{z}}$ on the basis of the first-order, irreversible rainout scheme used in their three-dimensional model, and obtained global mean values ranging from 2-12 days at $1 \mathrm{~km}$ to $10-35$ days at $8 \mathrm{~km}$ depending on the origin of the aerosol. We choose to define $\tau_{\mathrm{z}}$ here as the tropospheric residence time $\mathrm{C} / \Phi$ of ${ }^{210} \mathrm{~Pb}$ computed in a simulation where production of ${ }^{210} \mathrm{~Pb}$ is confined to altitude $z$; we find global mean values for $\tau_{\mathrm{z}}$ in July of 4.4 days in the lowest 0.5 $\mathrm{km}$ of atmosphere, 11 days at $4 \mathrm{~km}$, and 17 days at $9 \mathrm{~km}$, which is qualitatively consistent with values derived by previous authors. Aerosol produced in the mixed layer is thus largely confined to its region of origin, whereas aerosol produced in the upper troposphere can be transported on a hemispheric scale.

\section{CONCLUSIONS}

We have used a global three-dimensinal model based on the GISS GCM to simulate the transport and residence time of ${ }^{210} \mathrm{~Pb}$ aerosol in the troposphere. Our work improves on previous global models by computing aerosol scavenging in convective precipitation as part of the operator for wet convective mass
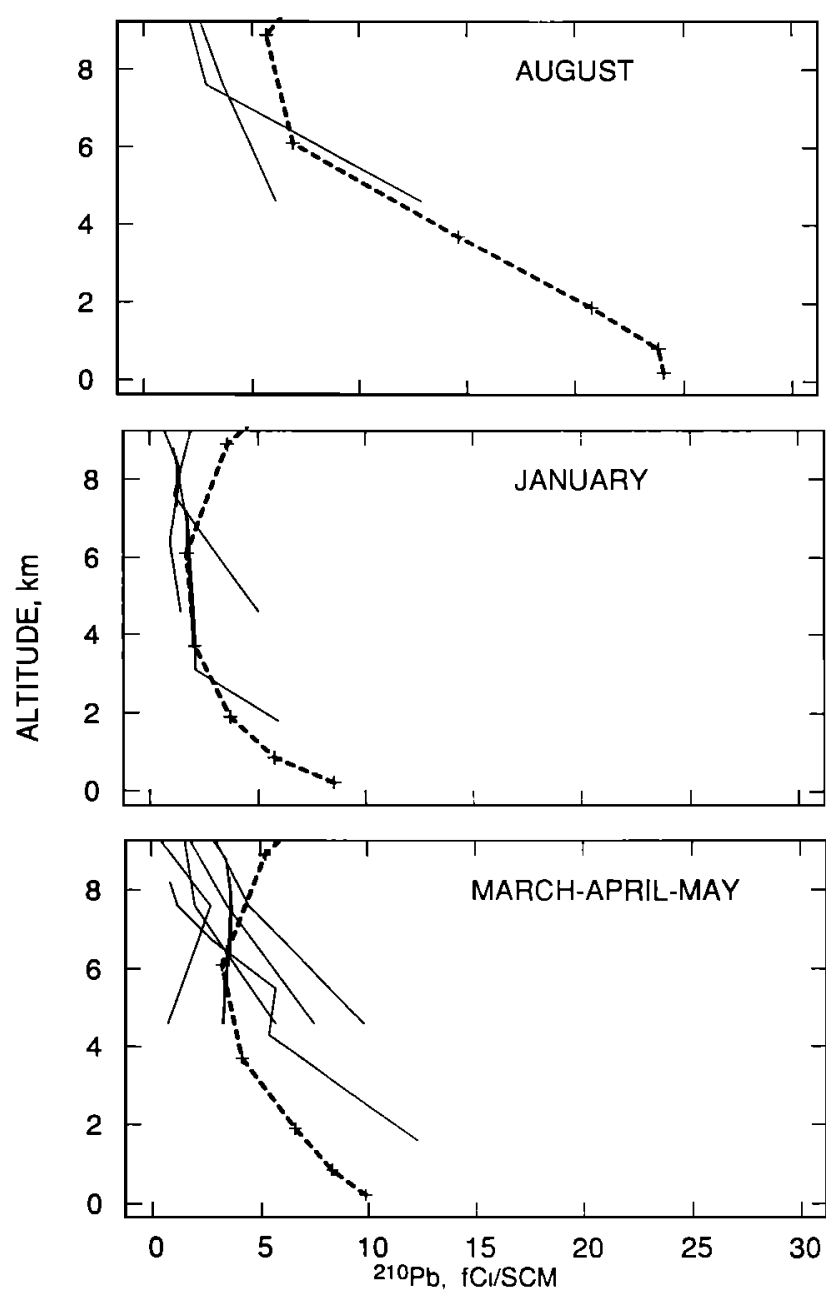

Fig. 8. Vertical profiles of ${ }^{210} \mathrm{~Pb}$ concentrations over the west-central United States. The solid lines are observations from 11 aircraft flights by Moore et al. [1973]. The dashed lines are model means for the appropriate months and for the grid boxes sampled by the flights. 


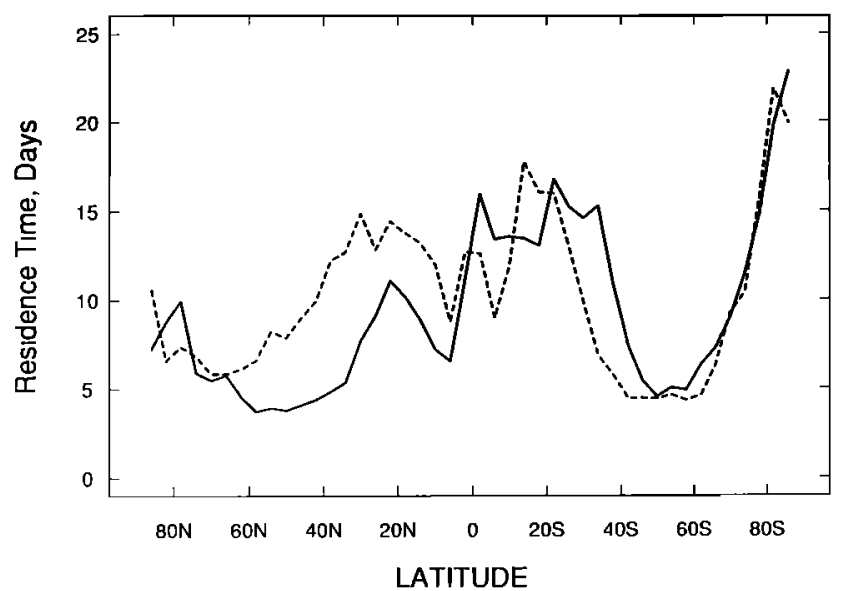

Fig. 9. Zonal mean tropospheric residence time of ${ }^{210} \mathrm{~Pb}$ in the model as a function of latitude for January (solid line) and July (dashed line).

transport rather than separately with a first-order rainout scheme. The model captures $63 \%$ of the variance of yearly mean ${ }^{210} \mathrm{~Pb}$ concentrations measured at 85 sites around the world and $34 \%$ of the variance of total deposition fluxes measured at 55 sites $(54 \%$ if the four sites with highest fluxes are excluded). There is negligible mean bias on the global scale in the simulations of concentrations and total deposition fluxes, lending some confidence in the scheme used to compute aerosol scavenging.

We have reported a number of regional and seasonal discrepancies between model and observations. These discrepancies may reflect in part the variability of ${ }^{222} \mathrm{Rn}$ emission, which needs to be better understood. Anomalies in GCM precipitation are another source of discrepancy. Indeed, the difficulty of representing precipitation in global meteorological models probably limits our ability to describe the details of the spatial distribution of soluble tracers. Climatological precipitation data are of little help in that regard, as the critical variables determining aerosol scavenging are the convective mass flux and the precipitation frequency, for which no routine observations are available.

A salient feature of our model results is the prediction of relatively high ${ }^{210} \mathrm{~Pb}$ concentrations in the free troposphere, consistent with the few measurements of ${ }^{210} \mathrm{~Pb}$ concentrations at altitude. By contrast, total aerosol concentrations measured over continents typically show an order of magnitude decrease between the continental mixed layer and the free troposphere. An explanation is that aerosols and soluble aerosol precursors are scavenged in wet convective updrafts but ${ }^{222} \mathrm{Rn}$ is not. Thus ${ }^{210} \mathrm{~Pb}$ should not be viewed as a generic tracer of continental aerosols. An analogy can, however, be drawn between ${ }^{210} \mathrm{~Pb}$ and nitrate, whose precursor $\left(\mathrm{NO}_{\mathbf{x}}\right)$ is sparingly soluble. Long-range transport of continental nitrate at high altitudes followed by subsidence over the oceans could explain the strong correlations between ${ }^{210} \mathrm{~Pb}$ and nitrate concentrations observed at island sites. Concurrent measurements of ${ }^{210} \mathrm{~Pb}$ and nitrate concentrations at high altitudes would test this hypothesis.

Mean residence times of ${ }^{210} \mathrm{~Pb}$ aerosol in the tropospheric column in the model are 20 days over Antarctica, 5 days at southern midlatitudes, and 10-15 days in the tropics. Residence times at northern midlatitudes vary from about 5 days in winter to 10 days in summer. The long residence times in the tropics and at northern midlatitudes in summer are due to frequent convective pumping of ${ }^{222} \mathrm{Rn}$ to high altitudes. The mean residence time for aerosol produced at $9-\mathrm{km}$ altitude is about four times longer than that for aerosol produced in the lowest $0.5 \mathrm{~km}$ of atmosphere.
Acknowledgements. The work at Harvard was funded by the National Science Foundation (grant NSF-ATM-89-22971), the National Aeronautics and Space Administration (grant NASA-NAGW-2632), and the Packard Foundation. The work at Yale was funded by the National Science Foundation (NSF-ATM-86-13751 and ATM-90-12950). We acknowledge valuable discussions with J.E. Dibb (University of New Hampshire), M.J. Prather (University of California Irvine), and our Harvard colleagues J.A Logan, C.M. Spivakovsky, and S.C. Wofsy.

\section{REFERENCES}

Balkanski, Y.J., Atmospheric residence times of continental aerosols, Ph.D. thesis, Harvard Univ., Cambridge, Mass., 1991.

Balkanski, Y.J., and D.J. Jacob, Transport of continental air to the subantarctic Indian Ocean, Tellus Ser. B 42, 62-75, 1990.

Balkanski, Y.J., D.J. Jacob, R. Arimoto, and M.A. Kritz, Long-range transport of radon-222 over the North Pacific Ocean: Implications for continental influence, J. Atmos. Chem., 14 353-374, 1992.

Barrie, L. A., Arctic air pollution: An overview of current knowledge, Atmos. Environ., 20, 643-663, 1986.

Bondietti, E.A., C. Papastefanou, and C. Rangarajan, Aerodynamic size associations of natural radioactivity with ambient aerosols, in Radon and Its Decay Products: Occurrence, Properties, and Health Effects, edited by P.K. Hopke, ACS Symp. Ser. 331, 377-397, 1987.

Bondietti, E.A., J.N. Brantley, and C. Rangarajan, Size distributions and growth of natural and Chernobyl-derived submicron aerosols in Tennessee, J. Environ. Radioact., 6, 99-120, 1988.

Bonnyman, J., J.C. Duggleby, and J. Molina-Ramos, Lead-210 in the Australian environment 1964-1970, in The Natural Radiation Environment II, Energy Res. Dev. Admin. Conf. 720805, pp. 819-832, 1972.

Charlson, R.J., J. Langner, H. Rodhe, C.B. Leovy, and S.G. Warren, Perturbation of the northern hemisphere radiative balance by backscattering from anthropogenic sulfate aerosols, Tellus, 43, 152-163, 1991.

Charlson, R.J., S.E. Schwartz, J.M. Hales, R.D. Cess, J.A. Coakley, Jr., J.E. Hansen, and D.J. Hofmann, Climate forcing by anthropogenic aerosols, Science, 255, 423-430, 1992.

Chatfield, R.C., and P.J. Crutzen, Sulfur dioxide in remote oceanic air: Cloud transport of reactive precursors, J. Geophys. Res., 89, 7111-7132, 1984.

Dana, M.T., and J.M. Hales, Statistical aspects of the washout of polydisperse aerosols, Atmos. Environ., 10, 45-50, 1976.

Dibb, J.E., and J.-L. Jaffrezo, Beryllium-7 and lead-210 in aerosol and snow in the Dye 3 Gas, Aerosol and Snow Sampling Program, Atmos. Environ, in press, 1993.

Dickerson, R.R., et al. Thunderstorms: An important mechanism in the transport of air pollutants, Science, 235, 460-465, 1987.

Dorr, H., and K.O. Munnich, ${ }^{222}$ Rn flux and soil air concentration profiles in West Germany. Soil ${ }^{222} \mathrm{Rn}$ as a tracer for gas transport in the unsaturated soil zone, Tellus Ser. B 42, 20-28, 1990.

Ehhalt, D. H., Turnover times of ${ }^{137} \mathrm{Cs}$ and HTO in the troposphere and removal rates of natural particles and water vapor, J. Geophys. Res., 78, 7076-7086, 1973.

Feely, H.W., R.J. Larsen, and C.G. Sanderson, Annual report of the surface air sampling program, Rep. EML-497, Environ. Meas. Lab., Dep. of Energy, New York, 1988.

Feichter, J., R.A. Brost, and M. Heimann, Three-dimensional modeling of the concentration and deposition of ${ }^{210} \mathrm{~Pb}$ aerosols, J. Geophys. Res., $96,22,447-22,460,1991$

Gatz, D.F., A review of chemical tracer experiments on precipitation systems, Atmos. Environ., 11, 945-973, 1977.

Giorgi, F., and W.L. Charneides, Rainout lifetimes of highly soluble aerosols and gases as inferred from simulation with a general circulation model, J. Geophys. Res., 91, 14,367-14,376, 1986.

Graustein, W.C., and K.K. Turekian, ${ }^{210} \mathrm{~Pb}$ and ${ }^{137} \mathrm{Cs}$ in air and soils measure the rate and vertical profile of aerosol scavenging, J. Geophys. Res., 91, 14,355-14,366, 1986. 
Graustein, W.C., and K.K. Turekian, Radon fluxes from soils to the atmosphere measured by $210 \mathrm{~Pb}-226 \mathrm{Ra}$ disequilibrium in soils, Geophys. Res. Lett., 17, 841-844, 1990.

Gregory, G.L., E.V. Browell, L.S. Warren, and C.H. Hudgins, Amazon Basin ozone and aerosol: Wet season observations, J. Geophys. Res., 95. 16,903-16,912, 1990.

Gregory, G.L., B.E. Anderson, L.S. Warren, E.V. Browell, D.R. Bagwell, and C.H. Hudgins, Tropospheric ozone and aerosol observations: The Alaskan Arctic, J. Geophys. Res., 97, 16,451-16,573, 1992.

Hansen, J., G. Russell, D. Rind, P. Stone, A. Lacis, S. Lebedeff, R. Ruedy, and L. Travis, Efficient three-dimensional global models for climate studies: Models I and II, Mon. Weather Rev., 111, 609-662, 1983.

Hicks, B.B., D.R. Matt, R.T. McMillen, J.D. Womack, M.L. Wesely, R.L. Hart, D.R. Cook, S.E. Lindberg, R.G. de Pena, and D.W. Thompson, A field investigation of sulfate fluxes to a deciduous forest, $J$. Geophys. Res., 94, 13,003-13,011, 1989.

Jacob, D.J., and M.J. Prather, Radon-222 as a test of boundary layer convection in a general circulation model, Tellus Ser. B 42, 118-134, 1990.

Jacob, D. J., M. J. Prather, S. C. Wofsy, and M. B. McElroy, Atmospheric distribution of ${ }^{85} \mathrm{Kr}$ simulated with a general circulation model, $J$. Geophys. Res., 92, 6614-6626, 1987.

Jacob, D.J., et al., Simulation of summertime ozone over North America, $J$. Geophys. Res., 98, 14,797-14,826, 1993.

Jones, D.M.A., and A.L. Sims, Climatology of instantaneous rainfall rates, J. Appl. Meteorol., 17, 1135-1140, 1976.

Joussaume, S., Three-dimensional simulation of the atmospheric cycle of desert dust particles using a general circulation model, J. Geophys. Res., 95, 1909-1941, 1990.

Kiehl, J.T., and B.P. Briegleb, The relative role of sulfate aerosols and greenhouse gases in climate forcing, Science, 260, 311-314, 1993.

Kritz, M.A., J-C. Le Roulley, and E.F. Danielsen, The China Clipper: Fast advective transport of radon rich air from the Asian boundary layer to the upper troposphere near California, Tellus Ser. B 42, 46-61, 1990.

Lambert, G., G. Polian, J. Sanak, B. Ardouin, A. Buisson, A. Jegou, and J. C. Leroulley, Cycle du radon et de ses descendants: Application à l'étude des échanges troposphère-stratosphère, Ann. Geophys., 38, 497$531,1982$.

Martell, E.A., and H.E. Moore, Tropospheric aerosol residence times: A critical review, J. Rech. Atmos. B, 8, 903-910, 1974.

Matthews, E., Global vegetation and land use: New high-resolution data bases for climate studies, J. Clim. Appl. Meteorol., 22, 474-487, 1983.

Merrill, J.T., Atmospheric long-range transport to the Pacific ocean, in Chem. Oceanogr., 10, 15-49, 1990.

Mishra, U.O., O. Rangarajan, and C.D. Eapen, Natural radioactivity of the atmosphere over the Indian land mass, inside deep mines, and over adjoining oceans, in The Natural Radiation Environment III, U.S. Dep. of Energy Symp. Ser. 51, 327-346, 1980.

Moed, B.A., W.W. Nazaroff, A.V. Nero, M.B. Schweh, and A. Van Heuvelen, Identifying areas with potential for high indoor radon levels: Analysis of the national airborne radiometric reconnaissance data for California and the Pacific Northwest, Rep. LBL-16955, Univ, of Calif. Berkeley, 1984.

Moore, H.E., S.E. Poet, and E.A. Martell, ${ }^{222} \mathrm{Rn},{ }^{210} \mathrm{~Pb},{ }^{210} \mathrm{Bi}$, and ${ }^{210} \mathrm{Po}$ profiles and aerosol residence times versus altitude, J. Geophys. Res., 78, 7065-7075, 1973.

Moore, H.E., S.E. Poet, and E.A. Martell, Size distribution and origin of lead-210, bismuth-210, and polonium-210 on airborne particles in the troposphere, in The Natural Radiation Environment III, NTIS-CONF780244, edited by T.F. Gesell and W.M. Lowder, pp. 281-293, Natl. Tech. Info. Serv., Springfield, Va, 1980.

Olsen, C.R., I.L. Larsen, N.H. Cutshall, J.F. Todd, G.T.F. Wong, and W.H. Casey, Atmospheric fluxes and marsh-soil inventories of ${ }^{7} \mathrm{Be}$ and ${ }^{210} \mathrm{~Pb}$, J. Geophys. Res., 90, 10,487-10,495, 1985.

Penner, J.E., S.J. Ghan, and J.J. Walton, The role of biomass burning in the budget and cycle of carbonaceous soot aerosols and their climate impact, in Global Biomass Burning: Atmospheric, Climatic, and Biospheric Implications, edited by J.S. Levine, pp. 387-393, MIT Press, Cambridge, Mass., 1991.

Prather, M.J., M.B. McElroy, S.C. Wofsy, G. Russell, and D. Rind, Chemistry of the global troposphere: Fluorocarbons as tracers of air motion, J. Geophys. Res., 92, 6579-6613, 1987.

Prospero, J.M., and R.T. Nees, Impact of the north African drought and El Nino on mineral dust in the Barbados trade winds, Nature, 320. 735-738, 1986.

Rodhe, H., Precipitation scavenging and tropospheric mixing, in Precipitation Scavenging, Dry Deposition, and Resuspension, edited by H.R. Pruppacher et al., pp. 719-729, Elsevier, New York, 1983.

Sanak, J., A. Gaudry, and G. Lambert, Size distribution of Pb-210 aerosols over oceans, Geophys. Res. Lett., 8, 1067-1070, 1981.

Sancho, P., J. de la Cruz, A. Diaz, F. Martin, E. Hernandez, F. Valero, and B. Albarran, A five-year climatology of back-trajectories from the Izanã baseline station, Tenerife, Canary Islands, Atmos. Environ., 26, 10811096, 1992.

Savoie, D. L., J. M. Prospero, J. T. Merrill, and M. Uematsu, Nitrate in the atmospheric boundary layer of the tropical South Pacific: Implications regarding sources and transport, J. Atmos. Chem., 8, 391-398, 1989.

Savoie, D.L., J.M. Prospero, S.J. Oltmans, W.C. Graustein, K.K. Turekian, J.T. Merrill, and H. Levy II, Sources of nitrate and ozone in the marine boundary layer of the tropical North Atlantic, J. Geophys. Res., 97, 11,575-11,589, 1992.

Schery, S. D., S. Whittlestone, K. P. Hart, and S. E. Hill, The flux of radon and thoron from Australian soils, J. Geophys. Res., 94, 8567-8576, 1989.

Schwartz, S. E, Are global cloud albedo and climate controlled by marine phytoplankton?, Nature, 336, 441-445, 1988.

Seinfeld, J. H., Atmospheric Chemistry and Physics of Air Pollution, pp. 509-511, John Wiley, New York, 1986.

Spivakovsky, C.M., R. Yevich, J.A. Logan, S.C. Wofsy, M.B. McElroy, and M.J. Prather, Tropospheric $\mathrm{OH}$ in a three dimensional chemical tracer model: An assessment based on observations of $\mathrm{CH}_{3} \mathrm{CCl}_{3}, J$. Geophys. Res., 95, 18,441-18,472, 1990

Todd J.F., G.T.F. Wong, C.R. Olsen, and I.L. Larsen, Atmospheric depositional characteristics of beryllium 7 and lead 210 along the southeastern Virginia coast, J. Geophys. Res., 94, 11,106-11,116. 1989.

Tsunogai, S., T. Kurata, T. Suzuki, and K. Yokota, Seasonal variation of atmospheric ${ }^{210} \mathrm{~Pb}$ and $\mathrm{Al}$ in the western North Pacific region, J. Atmos. Chem., 7, 389-407, 1988.

Turekian, K.K., Y. Nozaki, and L.K. Benninger, Geochemistry of atmospheric radon and radon products, Annu. Rev. Earth Planet. Sci., 5. 227-255, 1977.

Turekian, K.K., W.C. Graustein, and J.K. Cochran, Lead-210 in the SEAREX program: An aerosol tracer across the Pacific, Chem. Oceanogr., 10, 51-80, 1990.

Twomey, S., Aerosols, clouds and radiation, Atmos. Environ., 25, 24352442, 1991 .

Ussler, W. III, P.S. Bakwin, and C.S. Martens, Determining vertical trace gas transport within the atmospheric boundary layer using radon-222: Preliminary results from a tall tower in eastern North Carolina, EOS Trans. AGU, 74 (10), Spring Meeting Suppl., 70, 1993.

Voldner, E.C., L.A. Barrie, and A. Sirois, A literature review of dry deposition of oxides of sulfur and nitrogen with emphasis on long-range transport modelling in North America, Atmos. Environ., 20, 2101-2123, 1986.

Wagenbach, D., U. Gorlach, and K. Moser, Coastal Antarctic aerosol: The seasonal pattern of its chemical composition and radionuclide content, Tellus Ser. B 40, 426-436, 1988.

Wesely, M.L., D.R. Cook, R.L. Hart, and R.E. Speer, Measurements and parameterization of particulate sulfur dry deposition over grass, $J$. Geophys. Res., 90, 2131-2143, 1985.

Wilkening, M.H., and W.E. Clements, Radon 222 from the ocean surface, J. Geophys. Res., 80, 3828-3830, 1975.

Wilkening, M.H., W.E. Clements and D. Stanley, Radon 222 flux 
measurements in widely separated regions, in The Natural Radiation Environment II, pp. 717-730, U.S. Energy and Research Development Administration, Oak Ridge, 1972.

Xing, L., and W.L. Chameides, Model simulations of rainout and washout from a warm stratiform cloud, J. Atmos. Chem., 10, 1-26, 1990.

Y. J. Balkanski, G. M. Gardner and D. J. Jacob, Department of Earth and Planetary Sciences, Harvard University, Pierce Hall, 29 Oxford Street, Cambridge, MA 02138.

W. C. Graustein and K. K. Turekian, Department of Geology and Geophysics, Yale University, New Haven, CT 06511.

(Received December 15, 1992; revised August 20, 1993; accepted August 20, 1993.) 